\title{
Proteomic Analysis of HIV-Infected Macrophages
}

\author{
Loyda M. Meléndez • Krystal Colon • Linda Rivera • \\ Eillen Rodriguez-Franco • Dianedis Toro-Nieves
}

Received: 2 July 2010 /Accepted: 23 November 2010 /Published online: 14 December 2010

(C) The Author(s) 2010. This article is published with open access at Springerlink.com

\begin{abstract}
Mononuclear phagocytes (monocytes, macrophages, and microglia) play an important role in innate immunity against pathogens including HIV. These cells are also important viral reservoirs in the central nervous system and secrete inflammatory mediators and toxins that affect the tissue environment and function of surrounding cells. In the era of antiretroviral therapy, there are fewer of these inflammatory mediators. Proteomic approaches including surface enhancement laser desorption ionization, one- and two-dimensional difference in gel electrophoresis, and liquid chromatography tandem mass spectrometry have been used to uncover the proteins produced by in vitro HIV-infected monocytes, macrophages, and microglia. These approaches have advanced the understanding of novel mechanisms for HIV replication and neuronal damage. They have also been used in tissue macrophages that restrict HIV replication to understand the mechanisms of restriction for future therapies. In this review, we summarize the proteomic studies on HIV-infected mononuclear phagocytes and discuss other recent proteomic approaches that are starting to be applied to this field. As proteomic instruments and methods evolve to become more sensitive and quantitative, future studies are likely to identify more proteins that can be targeted for diagnosis or therapy and to uncover novel disease mechanisms.
\end{abstract}

L. M. Meléndez $(\bowtie) \cdot K$. Colon $\cdot$ L. Rivera $\cdot$ E. Rodriguez-Franco Department of Microbiology and Medical Zoology, School of Medicine, University of Puerto Rico,

Medical Sciences Campus,

San Juan 00935, Puerto Rico

e-mail: loyda.melendez@upr.edu

D. Toro-Nieves

NeuroAIDS Program, University of Puerto Rico,

Medical Sciences Campus,

San Juan, Puerto Rico
Keywords Monocytes - Macrophages · HIV

SELDI-TOF - 2D DIGE - Tandem mass spectrometry . Proteomics

\begin{tabular}{|c|c|}
\hline Abbrev & \\
\hline 2D DIGE & $\begin{array}{l}\text { Two-dimensional difference in gel } \\
\text { electrophoresis }\end{array}$ \\
\hline AIDS & $\begin{array}{l}\text { Acquired immunodeficiency } \\
\text { syndrome }\end{array}$ \\
\hline BBB & Blood-brain barrier \\
\hline $\mathrm{CI}$ & Cognitive impairment \\
\hline $\mathrm{CNS}$ & Central nervous system \\
\hline $\mathrm{CSF}$ & Cerebrospinal fluid \\
\hline GEE & Generalized estimating equation \\
\hline HAD & HIV-1 associated dementia \\
\hline HAND & $\begin{array}{l}\text { HIV-associated neurological } \\
\text { disorders }\end{array}$ \\
\hline HBMEC & $\begin{array}{l}\text { Human brain microvascular } \\
\text { endothelial cell }\end{array}$ \\
\hline HIV ADA & $\begin{array}{l}\text { A macrophage tropic } \mathrm{R} 5 \text { virus } \\
\text { isolated from blood of a patient } \\
\text { with HIV dementia }\end{array}$ \\
\hline HPLC & $\begin{array}{l}\text { High-performance liquid } \\
\text { chromatography }\end{array}$ \\
\hline ICAT & Isotope coded affinity tags \\
\hline IFN & Interferon \\
\hline IL-1 $\beta$ & Interleukin-1 $\beta$ \\
\hline ITRAQ & $\begin{array}{l}\text { Isobaric tag for relative and } \\
\text { absolute quantitation }\end{array}$ \\
\hline LC/ESI-FTICR MS & $\begin{array}{l}\text { Liquid chromatography coupled } \\
\text { with electrospray ionization } \\
\text { and a hybrid quadrupole linear } \\
\text { ion-trap and Fourier-transform } \\
\text { ion-cyclotron-resonance mass } \\
\text { spectrometry }\end{array}$ \\
\hline
\end{tabular}




$\begin{array}{ll}\text { LC/MS/MS } & \text { Liquid chromatography/mass } \\ \text { spectrometry/mass spectrometry } \\ \text { LTQ-FT } & \begin{array}{l}\text { Linear ion trap Fourier transform } \\ \text { instrument }\end{array} \\ \text { M-tropic } & \text { Macrophage tropic } \\ \text { M-tropism } & \text { Macrophage-tropism } \\ \text { MALDI-MS } & \text { Matrix assisted laser desorption/ } \\ & \text { ionization-mass spectrometry } \\ \text { MALDI-TOF } & \text { Matrix-assisted laser desorption } \\ & \text { ionization/time of flight } \\ \text { MCMD } & \text { Minor cognitive motor disorder } \\ \text { MDM } & \text { Monocyte derived macrophage } \\ \text { MS } & \text { Mass spectrometry } \\ \text { NC } & \text { Normal cognition } \\ \text { PM } & \text { Placental macrophages } \\ \text { PTMs } & \text { Post-translational modifications } \\ \text { PY } & \text { Tyrosine phosphorylation } \\ \text { Q-TOF } & \text { Quadrupole time-of-flight } \\ \text { SDS PAGE } & \text { Sodium dodecyl sulfate } \\ & \text { polyacrylamide gel electrophoresis } \\ \text { SELDI } & \text { Surface enhancement laser } \\ & \text { desorption/ionization } \\ \text { SELDI-TOF } & \text { Surface-enhanced laser desorption/ } \\ & \text { ionization time-of-flight } \\ \text { SILAC } & \text { Stable isotope labeling of cells } \\ & \text { in culture } \\ \text { SIV } & \text { Simian immunodeficiency virus } \\ \text { SOD } & \text { Superoxide dismutase } \\ \text { STAT-1 } & \text { Signal transducer and activator of } \\ & \text { transcription-1 } \\ \text { THP-1 } & \text { A monocyte cell line } \\ \text { TNF } & \text { Tumor necrosis factor } \\ \text { VSV } & \text { Vesicular stomatitis virus } \\ & \end{array}$

\section{Macrophages and HIV infection: early evidence}

When HIV infection was first discovered in 1981, multiple studies pointed to CD4+ T cells as the only targets of infection (Maddon et al. 1986). A few years later, new evidence revealed that different HIV isolates could productively infect other CD4+ cells including monocytes and macrophages (Cheng-Mayer et al. 1988; Gendelman et al. 1988; Collman et al. 1989). Macrophages are mononuclear phagocytes involved in both innate and adaptive immune responses. These cells act as sentinels of the immune system because of their phagocytic and inflammatory functions. Those HIV isolates that preferentially infect macrophages are termed macrophage tropic (M-tropic) or non-syncytia inducing, whereas those that productively infect $\mathrm{CD} 4+\mathrm{T}$ cells are termed $\mathrm{T}$ cell tropic or syncytia-inducing based on the phenotype developed after infection. HIV uses the CCR5
(R5), and the CXCR4 (X4), as co-receptors for entry (Alkhatib et al. 1996; Deng et al. 1996). In addition, several groups have provided evidence of the dual usage of chemokine co-receptors by some viral isolates (Doranz et al. 1996). A classification system was developed wherein viral isolates were designated as $\mathrm{R} 5, \mathrm{X} 4$, or R5X4 viruses, depending on co-receptor usage (Berger et al. 1998). Shortly after identification of co-receptors for HIV entry, it was demonstrated that co-receptor use cannot be assumed to be a surrogate for tropism, owing to the presence of dual-tropic viral strains that are X4 but not R5 or vice versa (Goodenow and Collman 2006). CD4(+) T cells and macrophages can be infected by R5-using viruses, as they both bear R5 coreceptors (Duenas-Decamp et al. 2010; Hladik et al. 1999), but R5-using viruses vary in their capacity to infect macrophages (Duenas-Decamp et al. 2010; Tuttle et al. 2002). The presence of $\mathrm{X} 4$ viruses correlates with risk of disease progression (Raymond et al. 2010; Tuttle et al. 2002). But highly macrophage-tropic R5 viruses have been related to neurological complications (Peters et al. 2007). HIV-1 disease progression is also associated with an increased capacity of the virus to replicate in macrophages, indicating that M-tropism of HIV-1 is an important determinant (Gendelman et al. 1990; Li et al. 1999; Tuttle et al. 2002; as reviewed by Gorry et al. 2005). During initial viral transmission in vivo, preferential infection is via M-tropic, R5 viruses (Bieniasz and Cullen 1998; Bachis et al. 2010; Raymond et al. 2010). X4 viruses in primary infections are not usual (Raymond et al. 2010). Macrophages are to be among the first cells infected with HIV-1 following sexual transmission (Zhu et al. 1993) although cervical mucosa CD4(+) T cells can also be infected as they possess CXCR4 and CCR5 co-receptors (Hladik et al. 1999), and R5 viruses from a few patients have been shown to replicate in $\mathrm{T}$ cells and not in macrophages (Li et al. 2010).

\section{Macrophages as HIV reservoirs}

HIV persists in the host system despite antiretroviral treatment. There are essentially two theories of persistent infection: ongoing replication, which is a consequence of drug resistance, and latency, which involves the presence of HIV in reservoir cells such as resting memory CD4+ T cells, and in mononuclear phagocytes including peripheral blood monocytes, macrophages, microglia, and dendritic cells (Le Douce et al. 2010; Embretson et al. 1993; Finzi et al. 1997; Chun et al. 1997; Wong et al. 1997; Bailey et al. 2006; Keele et al. 2008; Zhu 2002). Mononuclear phagocytes are important sites of viral persistence (Popovic et al. 1988; Gendelman et al. 1988; Le Douce et al. 2010). Since monocytes and tissue macrophages live for a long time, they can act as reservoirs and vehicles for viral dissemination 
(Crowe et al. 2003). Infectious virus is present not only in differentiated macrophages but also in circulating monocytes (Zhu et al. 2002; Lambotte et al. 2000) affecting cellular receptors (Melendez-Guerrero et al. 1990) and antigen presentation (Melendez-Guerrero et al. 1991). It has been shown that the CD16+ subset of monocytes is more permissive to HIV infection than CD16- cells (Ellery et al. 2007). These CD16+ monocytes are recruited to sites of infection or inflammation (Crowe et al. 2003; Alexaki and Wigdahl 2008), and represent an intermediate state of activation between monocytes and macrophages (Ancuta et al. 2009). Upon subsequent differentiation, they become resting cells and viral reservoirs in different tissues including the brain (Gartner 2000; Fischer-Smith et al. 2001).

\section{Macrophages and HIV-associated neurological disorders}

HIV-associated neurological disorders (HAND) is a repertoire of several central nervous system (CNS) disease manifestations caused by HIV infection in advanced stages of the disease that range from mild forgetfulness to frank dementia. CNS disease results as a consequence of the neuronal death caused by the secretion of soluble viral and cellular neurotoxins from activated and/or infected perivascular macrophages and microglia (Gonzalez-Scarano and Martin-Garcia 2005; Kaul et al. 2001). These neurotoxins include the cytokines [tumor necrosis factor- $\alpha(\mathrm{TNF}-\alpha)$ or interleukin-1 $\beta$ (IL-1 $\beta$ )] (Fischer-Smith and Rappaport 2005), excitatory amino acids (Dreyer and Lipton 1995; Yeh et al. 2000), chemokines that induce cellular inflammatory cascades, and viral proteins (Gonzalez-Scarano and Baltuch 1999; Kaul et al. 2001). The secretion of these factors, together with a severe dysregulation of the normal functions of macrophages, can lead to neuronal dysfunction and apoptosis (Adle-Biassette et al. 1995; Shi et al. 1998), resulting in the development of severe dementia commonly called HIV-1 associated dementia (HAD; Gonzalez-Scarano and Martin-Garcia 2005; Kaul et al. 2001).

Two theories of viral entry into the CNS currently prevail: cell-free entrance and the Trojan horse model. HIV can enter the brain as cell-free virus at an early stage of the disease (Banks et al. 2001). Once in the brain, HIV establishes productive infection mostly in the mononuclear phagocytes of the CNS. These include perivascular macrophages derived from blood monocytes, meningeal macrophages, macrophages of the choroid plexus, and the microglia. The perivascular macrophages and the microglia are the major HIV-producing cells in the CNS (Fischer-Smith et al. 2001; Williams and Hickey 2002; $\mathrm{Kim}$ et al. 2003, 2005, 2006). Mononuclear phagocytes are less susceptible to the cytopathic effects of HIV infection compared to lymphocytes (Collman et al. 1989). In contrast to lymphocytes, viral replication is more persistent in mononuclear phagocytes, which leads to a continuous low-level virus production for the lifespan of the cells.

The Trojan horse model establishes that HIV-infected blood monocytes traffic from the periphery to the brain and hence are the primary source of virus in the brain (Narayan et al. 1982; Peluso et al. 1985; Meltzer et al. 1990; Davis et al. 1992; Fischer-Smith et al. 2001; Williams and Blakemore 1990; Kim et al. 2003, 2005, 2006). Monocyte trafficking to the CNS is part of the normal turnover and is augmented with inflammation and viral infection (Hickey and Kimura 1988). HIV-infected monocytes have been shown to cross the blood-brain barrier (BBB) more efficiently than noninfected monocytes (Persidsky et al. 1999). More importantly, at late stages of the disease, when the immune system is highly compromised and the BBB is deteriorated, there is an increased accumulation of monocyte-derived macrophages (MDM) from the circulation in the brain. Most of macrophages accumulating in the perivascular space appear to be an activated CD14+/CD16+ blood monocyte subpopulation (Fischer-Smith et al. 2001; Williams et al. 2001), which is more permissive to HIV infection (Ellery et al. 2007; Jaworski et al. 2007) and is increased in patients with HAD (Pulliam et al. 1997). The activated CD14+/CD16+ population is elevated in the blood of Hispanic women taking antiretroviral therapy (unpublished) as well as in their cerebrospinal fluid (CSF; Agasalda et al. 2010). Altogether, current data support the influence of the peripheral compartment in the development HIV-induced CNS disease, as reviewed by Fischer-Smith et al. (2008).

\section{HIV alterations of cellular functions of macrophages: evidence before the proteomics era}

Perivascular macrophages and resident microglia are the principal targets for HIV in the CNS. As described above, these cells play an important role in HIV pathogenesis and persistence in the CNS due to the secretion of toxic factors that affect neuronal function and survival (Giulian et al. 1990). Understanding how HIV infection modulates the normal physiology of these cells and contributes to neuronal injury has been of great interest. A key question is how specific proteins are modulated during HIV infection and how such modulation affects neuronal survival. The initial evidence of modulation of host cellular proteins was gathered via the study of individual proteins as small components of the whole cellular system. The most widely used methods were one dimensional (1D) gel electrophoresis, high-performance liquid chromatography (HPLC), Western blot, peptide sequencing by mass spectrometry, enzymelinked immunosorbent assay (ELISA), flow cytometry, and 
electron microscopy. For example, in an early study Jiang et al. (2001) using several time-consuming and complex methods, which included supernatant fractionation, HPLC, and immunostaining, showed that glutamate is a mediator of neurotoxicity. The role of secreted arachidonic acid in neuronal injury was demonstrated by using HPLC, ELISA, and Southern blot (Genis et al. 1992). The group of Talley (1995) demonstrated the expression and activity of TNF- $\alpha$, after fractionation, HPLC, and immunostaining, that this protein promotes loss of viability in neurons treated with HIV-infected MDM conditioned media. Although valuable information was found by the methods available before the 1990s, investigations had to rely on known proteins and pathways and thus were limited in a way that proteomic analysis is not.

\section{Monocytes, macrophages, and microglia in the proteomics era}

Before the proteomics era fully developed, researchers accumulated vast databases from genome sequences, but it became clear that sequences were not enough to elucidate the cell's proteome or biological functions as their information is restricted to DNA and RNA. An organism's genome is quite stable, whereas its proteome is highly dynamic. Proteins are very difficult to predict from genomic data. The existence of an open-reading frame does not necessarily indicate the presence of a functional protein; one gene can give rise to more than one functional protein. Also, protein post-translational modifications (PTMs) are not marked on the genome, and more importantly mRNA concentration does not necessarily correlate with protein concentration (Pandey and Mann 2000). Protein modifications such as PTMs, alternative RNA splicing, RNA editing, and proteolytic processing give rise to a very diverse proteome (Link and LaBaer 2009). Generally, most diseases are the consequence of the absence or dysfunction of a protein. Proteomics is a rapidly evolving field that gives a comprehensive view of the characteristics and activity of all cellular proteins expressed at a given time under specific conditions. By studying the cell proteome and secretome, we can examine PTMs, interactions, localization, conformation, stability, and trace of their functions in the cell (Morrison et al. 2002). These proteomic-based techniques have replaced in part traditional identification methods that failed to provide answers to important questions in research.

Proteomic analyses vary according to the goal of the experiment and may include methods to enhance solubilization or reduce the complexity of the protein sample before protein separation. Classical methods of protein separation prior to identification include the 1D and two- dimensional (2D) gel electrophoresis analyses (Table 1). The disadvantages of 1D gel electrophoresis are its poor sensitivity and specificity for comparison of bands between experimental and control samples and the alteration in protein chemistry after denaturation prior to electrophoresis analysis. 2D gel electrophoresis is an effective starting point for protein purification because it gives an overview of the sample proteome. This method separates proteins on the basis of molecular weight and isoelectric focusing (O'Farrell 1975). In the past, 2D gel electrophoresis provided considerable variability between control and experimental samples due to technical difficulties with the different gels for comparison. The 2D difference in gel electrophoresis (2D DIGE) has recently evolved into a quantitative method because the sample is labeled with fluorescent dyes, thus enabling separation of up to three different samples within the same 2D gel, with an automated analysis program included for statistical analysis of differential expression (Decyder, GE). It is less timeconsuming than the classical 2D electrophoresis, as fewer gels are used, and the internal standard consisting of a pool from all samples, reduces variability (Table 1).

The surface-enhanced laser desorption/ionization timeof-flight (SELDI-TOF) is a mass spectrometry method that requires a minimal sample amount for analysis and involves the use of special chips with different types of surfaces for discovery and characterization of hydrophobic, cationic, or anionic proteins from biological samples (Table 1). It has been used to uncover signature profiles for possible biomarkers of HIV associated dementia in MDM and monocytes from HIV seropositive patients (Table 2), and from in vitro infected MDM and other tissue macrophages (Table 3). Of great importance in the HIV field, SELDITOF was used in the identification of the antiviral activity of CD8 T cell-derived anti-HIV factor (Zhang et al. 2002; Table 3).

Matrix-assisted laser desorption ionization/time of flight (MALDI-TOF) functions similarly to SELDI-TOF as both are mass spectrometry based and are used for analysis of complex peptide mixtures (Table 1). The obtained peptide mass fingerprint is subsequently compared to virtual fingerprints of protein sequences in databases, and the top-scoring proteins are retrieved as possible candidate proteins (Gevaert and Vandekerckhove 2000). Using MALDI-TOF and liquid chromatography/mass spectrometry/mass spectrometry (LC/MS/MS), Chertova et al. (2006) characterized proteins in HIV-1 virions produced from MDM infected with HIV clone NLAD8, an R5 virus (Table 3). Their findings revealed proteins related to cell signaling, intracellular trafficking, cytoskeleton, and activation of immune response systems that contributed to understanding the viral assembly process in macrophages (Chertova et al. 2006). Other studies integrating MALDI-TOF and 2D electropho- 
Table 1 Proteomics approaches applied to studies of HIV-infected macrophages

\begin{tabular}{|c|c|c|}
\hline Technique & Uses, advantages, and disadvantages & References \\
\hline \multirow{3}{*}{$\begin{array}{l}\text { One-dimensional SDS } \\
\text { polyacrylamide gel } \\
\text { electrophoresis (1DE) }\end{array}$} & $\begin{array}{l}\text { Standard mean for molecular weight } \\
\text { determination of entire proteins }\end{array}$ & Ciborowski et al. 2007 \\
\hline & $\begin{array}{l}\text { All bands are cut for protein identification } \\
\text { by LC/MS/MS }\end{array}$ & Luciano-Montalvo et al. 2008 \\
\hline & $\begin{array}{l}\text { Difficult to correlate protein expression } \\
\text { with identification data }\end{array}$ & Garcia et al. 2009 \\
\hline $\begin{array}{l}\text { Surface-enhanced laser desorption/ } \\
\text { ionization (SELDI) }\end{array}$ & $\begin{array}{l}\text { Detect protein profiles and enzymatic } \\
\text { activities. Increased sample throughput } \\
\text { Does not provide protein identification. }\end{array}$ & $\begin{array}{l}\text { Luo et al. 2003; Sun et al. 2004; Wojna et al. 2004; } \\
\text { Carlson et al. 2004; Kadiu et al. 2007; } \\
\text { Toro-Nieves et al. 2009; Wiederin et al. } 2009\end{array}$ \\
\hline $\begin{array}{l}\text { Matrix-assisted laser desorption/ } \\
\text { ionization time of flight } \\
\text { (MALDI-TOF) mass } \\
\text { spectrometry }\end{array}$ & $\begin{array}{l}\text { Vaporization and ionization of both small } \\
\text { and larger molecules, high accuracy, } \\
\text { and sub-picomole sensitivity }\end{array}$ & Chertova et al. 2006 \\
\hline $\begin{array}{l}\text { Electrospray ionization liquid } \\
\text { chromatography tandem mass } \\
\text { spectrometry (ESI LC/MS/MS) }\end{array}$ & $\begin{array}{l}\text { Ionize samples to obtain peptide sequences, } \\
\text { used with LC. Allows protein identification. }\end{array}$ & $\begin{array}{l}\text { Ciborowski et al. 2007; Kraft-Terry et al. 2010; } \\
\text { Wiederin et al. 2009; Ciborowski et al. } 2007\end{array}$ \\
\hline $\begin{array}{l}\text { Two-dimensional differential } \\
\text { in-gel electrophoresis (2D DIGE) }\end{array}$ & $\begin{array}{l}\text { Enables separating up to three samples with the } \\
\text { same 2D gel according to isoelectric point and } \\
\text { weight. Accurate analysis of differences in protein } \\
\text { concentration between samples. Includes an internal } \\
\text { standard. Difficult to detect membrane proteins and } \\
\text { low molecular weight proteins }\end{array}$ & $\begin{array}{l}\text { Kraft-Terry et al. 2010; Dukelow et al. 2007; } \\
\text { Kadiu et al. } 2009\end{array}$ \\
\hline
\end{tabular}

resis have shown macrophage dysfunction related to inflammatory and infectious diseases (Dupont et al. 2004). These studies showed the first two-dimensional maps of the human macrophage and secretome with a tremendous utility for understanding the biological functions of this immune cell.

$\mathrm{LC} / \mathrm{MS} / \mathrm{MS}$ or tandem mass spectrometry is the most sensitive technique used to identify proteins present in a biological sample (Table 1). This method works by ionizing molecules and sorting and identifying them according to their mass-to-charge $(\mathrm{m} / \mathrm{z})$ ratios (Jemal and Xia 2006). The importance of protein identification lies in the fact that each protein has a unique cell function that may be altered when, for example, an obligate parasite such as HIV-1 interacts with the cell causing a proteome unbalance that may correlate with disease pathogenesis.

Current in vitro and ex vivo studies of HIV-infected macrophages were done mostly with non-quantitative or semi-quantitative proteomic methods (Tables 2 and 3). One limitation of the proteomics approaches described in studies of patient MDM has been the amount of protein required by gel-based studies (Luo et al. 2003; Wojna et al. 2004; Table 2). Another limitation has been the challenge in verification of proteins in finding antibodies that recognize the same epitopes detected by MS/MS (Kraft-Terry et al. 2010; Table 2).

Recent advances in chromatography, MS, and bioinformatics demonstrate that proteomics studies are becoming quantitative and more functional as in the case of protein PTMs assessment. Some of the techniques currently of great interest are stable isotope labeling of cells in culture (SILAC), isobaric tag for relative and absolute quantitation (ITRAQ), isotope coded affinity tags (ICAT), and protein arrays (Table 4). Gel-free quantitative proteomics have been developed and offer the advantage of increased sensitivity for identification of low abundant, hydrophobic, and low molecular weight proteins. In general, these methods require advanced MS/MS and rely on highly sophisticated computational analyses programs. They include stable isotope labeling methods: SILAC, ITRAQ, and ICAT. They offer the advantages of high throughput proteomics analyses (Table 4).

In the SILAC method, experimental and control cells are labeled in cultures containing different types of media, one with a "heavy" arginine and lysine containing carbon $\left({ }^{13} \mathrm{C}\right)$ isotope and nitrogen isotope $\left({ }^{15} \mathrm{~N}\right)$ and "light" and media containing L-lysine and L-arginine. Subsequently, cell extracts are combined and analyzed with a high-resolution MS/MS or a linear ion trap Fourier transform instrument (LTQ-FT) or LTQ-Orbitrap, recently developed by ThermoFisher (Table 4). Originally, the SILAC approach was recommended for dividing cells that can easily incorporate these amino acids in culture while undergoing several cell divisions (Mann 2006). However, recent studies have demonstrated that even primary can incorporate these 
isotopes in culture (Spellman et al. 2008). Therefore, this method could potentially be applied to obtain quantitative protein analysis of HIV-infected MDM in vitro and ex vivo.

Other stable isotope labeling methods that can be performed after protein digestion include ICAT, ${ }^{18} \mathrm{O}$, and ITRAQ (Table 4). ICAT is used to compare proteins that are labeled with light and heavy tags carrying a biotin moiety. After cation exchange chromatography, the mixed peptides are purified using immobilized avidin. Peaks corresponding to the same peptide are identified as doublets in the mass spectra due to mass differences in the light and heavy isotopes. The peaks' intensities correlate with the relative abundance of the proteins in experimental and control samples. The limitation of this method is missed identification of proteins with few or no cysteine residues, loss of information for post-translational modifications, and complicated interpretation of spectra due to the biotin group (Wu et al. 2006). In the ${ }^{18} \mathrm{O}$ method, the protease catalyzes the incorporation of two ${ }^{18} \mathrm{O}$ atoms at the carboxy terminal end of peptides and increases their mass by $4 \mathrm{Da}$. The labeled sample is combined with the non-labeled one, and both are processed and analyzed by MS as doublets (Jorge et al. 2009). Sensitive statistical methods have been developed to analyze ${ }^{18} \mathrm{O}$ peptides with medium and high resolution mass spectrometers (Jorge et al. 2007). Large data sets have been generated by applying the ${ }^{18} \mathrm{O}$ method from plasma exposed to lipopolysaccharides (LPS) and from burn patients (Qian et al. 2005, 2010).

ITRAQ is the most sensitive quantitative proteomics method currently available (Table 4). A comparison of ITRAQ with ICAT, 2-D DIGE, and ITRAQ revealed a larger number of proteins identified by ITRAQ (Wu et al. 2006). This technology employs a 4- and 8-plex set of amine reactive isobaric tags to label lysine side chains at the Nterminus in a digested mixture. The Q-TOF mass spectrometer and the LTQ Orbitrap that can perform higher energy collision-induced dissociation are necessary for ITRAQ analysis. The Q-TOF quantitative proteomics requires the MASCOT analysis program; Orbitrap uses Proteome Discoverer for analyses (Casado-Vela et al. 2010). Recent studies applied iTRAQ to determine the role of T regulatory (Treg) cells in the proteome of HIV-infected MDM (Huang et al. 2010). ITRAQ using the LTQ Orbitrap has also been recently applied to studies of plasma from the simian immunodeficiency (SIV) monkey model of HIV encephalitis in search of biomarkers for HAND (Pendyala et al. 2010).

Protein PTMs (hydroxylations, methylations, nitrosylations, thiolations, $\gamma$-carbonylations, glycosylations, and phosphorylations) can alter a protein's function, structure, location, and life span. In the past, irreversible protein modifications were assessed using 2D gel electrophoresis, and spots of interest were identified using immunological procedures, specifically, with antibodies against PTMs, 


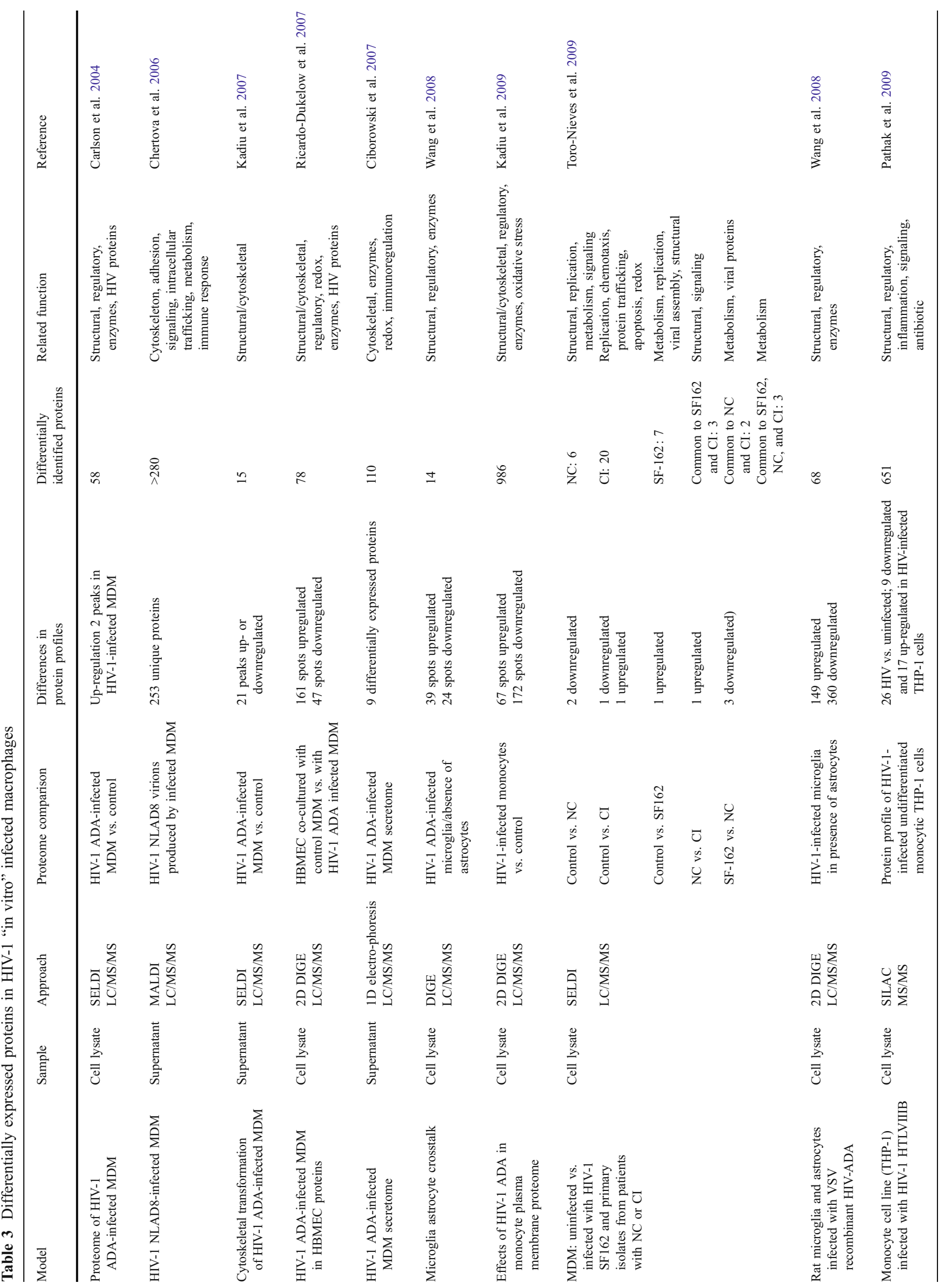


Table 4 Future proteomic methods for quantitative determinations of proteins and protein modifications

\begin{tabular}{|c|c|c|c|c|}
\hline Technique & Uses & Advantages & Disadvantages & References \\
\hline $\begin{array}{l}\text { Stable isotope } \\
\text { labeling of cells } \\
\text { in culture (SILAC) }\end{array}$ & $\begin{array}{l}\text { Cellular signaling and } \\
\text { protein-protein } \\
\text { interactions } \\
\text { LC-based quantitative } \\
\text { proteomics }\end{array}$ & $\begin{array}{l}\text { Inexpensive. Can be } \\
\text { used in dividing } \\
\text { and non-dividing cells }\end{array}$ & Requires cells in culture & $\begin{array}{l}\text { Spellman et al. } \\
\text { 2008; Ibarrola } \\
\text { et al. } 2003\end{array}$ \\
\hline $\begin{array}{l}\text { Stable Isotope } \\
\text { labeling post- } \\
\text { culture with } \\
\text { oxygen }\left({ }^{18} \mathrm{O}\right)\end{array}$ & $\begin{array}{l}\text { LC-based quantitative } \\
\text { proteomics }\end{array}$ & $\begin{array}{l}\text { Can be applied after protein } \\
\text { digestion. Can be done in } \\
\text { low and high resolution } \\
\text { mass spectrometers }\end{array}$ & $\begin{array}{l}\text { Sophisticated statistical } \\
\text { analysis }\end{array}$ & Jorge et al. 2009 \\
\hline $\begin{array}{l}\text { Stable isotope } \\
\text { labeling with } \\
\text { isotope coded } \\
\text { affinity tags (ICAT) }\end{array}$ & $\begin{array}{l}\text { LC-based quantitative } \\
\text { proteomics }\end{array}$ & $\begin{array}{l}\text { Can be applied after protein } \\
\text { digestion. Can be done in } \\
\text { low and high resolution } \\
\text { mass spectrometers }\end{array}$ & $\begin{array}{l}\text { Missed identification } \\
\text { of proteins with few } \\
\text { or no cysteine residues, } \\
\text { loss of information for } \\
\text { post-translational } \\
\text { modifications, and } \\
\text { complicated interpretation } \\
\text { of spectra due to the } \\
\text { biotin group }\end{array}$ & Wu et al. 2006 \\
\hline $\begin{array}{l}\text { Isobaric tags for } \\
\text { relative and } \\
\text { absolute } \\
\text { quantitation } \\
\text { (ITRAQ): 4plex } \\
\text { and 8plex }\end{array}$ & $\begin{array}{l}\text { LC-based quantitative } \\
\text { proteomics }\end{array}$ & $\begin{array}{l}\text { Can be applied after protein } \\
\text { digestion. Can be done in } \\
\text { low and high-resolution } \\
\text { mass spectrometers. Most } \\
\text { sensitive }\end{array}$ & $\begin{array}{l}\text { Requires a Nano LC ESI } \\
\text { MS MS QStar XL MS MS } \\
\text { or LTQ-Orbitrap for analysis. }\end{array}$ & Song et al. 2008 \\
\hline $\begin{array}{l}\text { Post-translational } \\
\text { modifications } \\
\text { (PTMs) } \\
\text { (a) Immovilized } \\
\text { metal affinity } \\
\text { chromatography }\end{array}$ & $\begin{array}{l}\text { (a) Protein purification } \\
\text { based in its affinity } \\
\text { for metal ions }\end{array}$ & $\begin{array}{l}\text { (a) More efficient for multiple } \\
\text { phosphorylated proteins }\end{array}$ & $\begin{array}{l}\text { (a) Non-specific binding } \\
\text { of acid peptides to the matrix }\end{array}$ & Kota et al. 2009 \\
\hline $\begin{array}{l}\text { (b) Phosphoprotein } \\
\text { isotope coded solid } \\
\text { phase Tag }\end{array}$ & $\begin{array}{l}\text { (b) Abundance of phospho- } \\
\text { proteins from digested } \\
\text { complex mixtures using } \\
\text { heavy or light stable } \\
\text { isotopes }\end{array}$ & $\begin{array}{l}\text { (b) Reliable quantitation } \\
\text { of O-phosphorylations }\end{array}$ & $\begin{array}{l}\text { (b) Cannot be applied to } \\
\text { phosphotyrosine residues, } \\
\text { bias toward pSer and } \\
\text { pThr residues }\end{array}$ & \\
\hline $\begin{array}{l}\text { Protein microarray } \\
\text { (a) Analytical } \\
\text { (b) Functional } \\
\text { (c) Reverse phase }\end{array}$ & $\begin{array}{l}\text { Protein abundance, } \\
\text { interactions, affinities } \\
\text { or activity }\end{array}$ & $\begin{array}{l}\text { Accurate, rapid, low } \\
\text { volume required }\end{array}$ & $\begin{array}{l}\text { Database needed, depends } \\
\text { on protein quality } \\
\text { within the chip }\end{array}$ & $\begin{array}{l}\text { Speer et al. 2005; } \\
\text { Charboneau et al. } \\
\text { 2002; Bertone } \\
\text { and Snyder } 2005\end{array}$ \\
\hline
\end{tabular}

such as nitrotyrosine (Dalle-Donne et al. 2006). Now PTMs can be analyzed using proteomic approaches, mostly MS/ MS, but other techniques are also used (Table 4). Cysteine oxidation and thiolation can be directly and easily detected by MS approaches (Dalle-Donne et al. 2006). Numerous protein activities depend on phosphorylation or dephosphorylation, that can occur in serine, threonine, tyrosine, and histidine residues. Using databases, investigators can predict possible phosphosites, but not all phosphosites are physically available to be phosphorylated or they simply are not used. Some useful databases for prediction of phosphosites are PHOSIDA, a PTM database that can predict phosphorylations, acetylations, and $\mathrm{N}$-glycosylations, and Phospho.ELM, a database designed exclusively for phosphosite prediction in eukaryotes. Ibarrola et al. (2003) used SILAC to quantitate the extent of phosphosites as well as to identify and quantitate novel phosphorylation sites. Other techniques such as immobilized metal affinity chromatography, which uses $\mathrm{Ga} 3+$ to enrich phosphopeptides from cell lysates and phosphoprotein isotope-coded solid-phase tag, which labels and enriches phosphopeptides from complex mixtures, have also been used for the proteomic analysis of phosphopeptides (Kota et al. 2009). More recently MS/MS/MS or $\mathrm{MS}^{3}$ methodologies have been applied to phophopeptide PTMs (Ulintz et al. 2009).

Another important feature of proteins is glycosylation. Proteins can be N-and/or O-glycosylated. N-gycosylation attaches to the nitrogen of asparagines or arginines; Oglycosylation attaches to the oxygen of serine, threonine, 
and tyrosine. Glycans can undergo changes from being very homogenous and simple to highly complex and heterogeneous structures. Because glycosylations are immunogenic, making a glycosylation profile is potentially useful for HIV vaccine development. Glycosylation of HIV proteins influences tropism, neutralization, viral infectivity, and viral processing (Graham et al. 2008). Go et al. (2009) used a combination of MALDI-MS and LC/ESI-FTICR MS, in addition to reverse-phase HPLC, to separate glycopeptides and to determine the glycosylation profile of two clade $\mathrm{C}$ recombinant HIV envelopes. Graham et al. (2008) assessed the glycosylation in all HIV and SIV proteins using 2D DIGE and either ESI-MS/MS or LTQ-ion trap-MS/MS.

There are three different types of protein microarrays: analytical, functional, and reverse phase. Analytical microarrays are mostly used to detect affinity and expression (Table 4). Usually antibodies are attached to a microscope slide to detect the protein or probe (Bertone and Snyder 2005). Functional microarrays, which contain full-length functional proteins or domains, are used to study activity or interactions: protein-protein, protein-RNA, protein-phospholipid, or protein-ligand (Bertone and Snyder 2005). The reverse phase microarray uses denaturated protein lysates fixed to the slide and then probed, whereas conventional microarrays immobilize the antibodies or probes. The reverse-phase technique has been used to detect either quantitative protein changes in healthy and diseased tissue (Charboneau et al. 2002) or PTMs (Speer et al. 2005).

\section{Proteomics of monocytes, macrophages in HIV replication}

HIV-1 infection alters the proteome and secretome of macrophages (Tables 2 and 3). How HIV-1 affects the intracellular and secreted proteins is incompletely understood. Several studies have shown that shortly after the viral protein gp120 interacts with the CD4 and the seven transmembrane $\mathrm{G}$ protein-coupled receptors, CCR5- or CXCR4-specific signaling pathways such as the intracellular calcium mobilization, PI-3K activation, phosphorylation of mitogen-activated protein kinases (MAPKs), ERK1/2, JNK/ SAPK, and p38 are engaged (Lee et al. 2005; Cicala et al. 2002). This HIV-1 activation of MAPKs leads to up- and downregulation of several genes and consequently influences the transcriptional and post-transcriptional events related to the formation of important cellular and viral proteins (Wahl et al. 2006). Consequently, the gp120-mediated activation of these protein kinases leads to the formation of pro-inflammatory cytokines and chemokines such as TNF- $\alpha$ and MCP-1, respectively, which can influence HIV-1 replication and cell functions (Del Corno et al.
2001; Lee et al. 2003). In monocytes, one of the functional consequences of viral exposure is the facilitation of protein transformation from the cytosol to the plasma membrane (Kadiu et al. 2009). The dysregulation of macrophage function is mediated by HIV envelope gp120 protein with cellular co-receptor activation that results in the inflammatory responses observed in HAD pathogenesis (Gendelman et al. 2006). Some reports have shown the involvement of CXCR4 in the gp120 macrophage/microglia activation with the induction of proinflammatory cellular pathways that may contribute to AIDS dementia (Bezzi et al. 2001).

Microarray studies or MDM transcriptome have provided larger data sets for pathway analysis than proteomics (Brown et al. 2008; Giri et al. 2009; Tsang et al. 2009; Ancuta et al. 2009; Van den Bergh et al. 2010). A macrophage proinflammatory M1 phenotype after HIV infection was demonstrated with increased mRNAs for calcium upregulation, cell cycle, apoptosis, MAPK, and cytokines/chemokines (Brown et al. 2008). Since many of the over-expressed mRNAs may not represent the final protein product owing to delays in translation, the authors were able to validate $\sim 18 \%$ of these proteins including calcium related and pro-apoptotic proteins (caspase 7). They concluded that HIV primes macrophages to a pro-inflammatory M1 phenotype that is independent of toll-like receptor activation (Brown et al. 2008). However, subsequent studies on the HIV-infected MDM transcriptome had the opposite result, an antiinflammatory phenotype (Giri et al. 2009; Tsang et al. 2009). Agreement with some aspects of these studies related to the mechanisms of evasion of innate immunity by HIV interaction with MDM has been confirmed by proteomics studies, with the activation of oxidative stress associated proteins, inflammation, and signaling cascades (Ciborowski et al. 2007; Luciano-Montalvo and Meléndez 2009; Toro-Nieves et al. 2009). Moreover, some inflammatory proteins identified from a large data set generated by quantitative proteomics from plasma exposed to LPS and from burn patients (Qian et al. 2005, 2010) are also present in monocytes from HIV-infected women (Velazquez et al. 2009; Kraft-Terry et al. 2010).

Proteomics of patient cells has spearhead research toward the diagnosis and treatment of HIV-related disease (Luo et al. 2003; Wojna et al. 2004; Kraft-Terry et al. 2010). These studies include the discovery of proteins as candidates for biomarkers for HIV associated cognitive dysfunction at different stages (Velazquez et al. 2009) as well as other HIV-associated cellular changes and pathologies (Rasheed et al. 2009). The validation of the protein candidates as biomarkers in different populations and the discovery of novel biomarkers and possible targets for therapies by more sensitive and quantitative proteomics approach remains to be studied. 


\section{Proteomics of placental macrophages and MDM: a model of HIV persistence}

The HIV-1 persistence in the monocyte-macrophage lineage has been explained by two theories: the lack of proviral gene expression (latency) and continuous viral expression without cytopathic effects (ongoing replication; Le Douce et al. 2010). Several traits of monocytemacrophage lineage make it an important source of viral persistence: the HIV-1 infection is generally non-lytic for these cells; they can harbor viruses longer than CD4+ T cells; and cells from monocyte-macrophage are more resistant to cytopathic effects. For example, microglial cells in the brain can produce viruses during their total lifespan (Williams et al. 2001). However, not all of the mononuclear phagocyte populations equally support viral growth. The placental macrophages (PM) are a target for HIV-1 infection inside the placenta, but these cells are also barriers to primary infection by HIV-1. They can be productively infected by laboratory strains and clinical isolates (Fear et al. 1998; Kesson et al. 1993, 1994; McGann et al. 1994; Meléndez-Guerrero et al. 1994; Meléndez et al. 2001; Plaud-Valentin et al. 1999), but they are less susceptible to HIV-1 than are MDM. Although PM express lower levels of HIV-1 receptor CD4 and co-receptors CCR5 and CXCR4 than do MDM, the receptor expression is not the sole determinants of HIV replication in these macrophages (Luciano-Montalvo et al. 2008; Torres et al. 2001; Melendez et al. 2001). In contrast to the consistent levels of replication exhibited by MDM, HIV replication in PM reaches a peak of viral replication around 3-7 days after infection and then decreases (Kesson et al. 1994). Furthermore, levels of replication in PM measured by production of HIV-1 viral capsid protein (p24) are ten times lower than in MDM (Plaud-Valentin et al. 1999), a finding that cannot be explained solely by co-receptor expression. The HIV-1 persistence in MDM and the low permissiveness exhibited by PM make them good candidates for the study of cellular factors involved in restriction of viral replication.

Proteomics platforms including SELDI-TOF, 1D SDS PAGE, and LC/MS/MS have been used as initial steps to identify protein candidates associated with HIV-1 restriction in PM and persistence in MDM. Twenty-seven protein peaks differentially expressed between uninfected and infected PM and MDM cell lysates were identified by SELDI-TOF, and 12 were correlated with proteins identified by LC/MS/MS (Table 5; Luciano-Montalvo et al. 2008). Proteins indentified included: profilin, protein S-100 A9 (calgranulin B), SH3 glutamic acid rich-like protein 1, SOD, and cystatin B (Table 5). Profilin and protein S-100 A9 (calgranulin B) have been reported to be associated with HIV-1 infection in both macrophages and T cells (Chertova et al. 2006; Kadiu et al. 2007; Ryckman et al. 2002). Differences between PM and
MDM cystatin B levels detected by Western blots and LC/MS/ MS, correlated well and showed the most significant difference with SELDI-TOF protein peaks in uninfected and HIV-1infected PM, as compared with MDM (Luciano-Montalvo et al. 2008). Cystatin B is a cysteine protease inhibitor identified as an important protein related to HIV-1 replication in macrophages. A low level of cystatin B has been associated with restriction of HIV in PM (Luciano-Montalvo et al. 2008) and most recently in microglia (Rodriguez-Franco et al. 2010), whereas a high level of cystatin B in MDM is associated with HIV persistence (Luciano-Montalvo et al. 2008). Cystatin B was found upregulated at 12 days post infection in MDM and PM (Luciano-Montalvo et al. 2008). Cystatin B was found over-expressed in the secretome of HIV-1-infected MDM (Ciborowski et al. 2007; Garcia et al. 2009), suggesting that this protein is linked to virus infection. This link was further demonstrated by showing decreased HIV replication in MDM treated with siRNA against cystatin B (Luciano-Montalvo et al. 2008). The signaling mechanisms for cystatin B in HIV replication are related to its interaction with signal transducer and activator of transcription-1 (STAT-1) as confirmed by co-immunoprecipitation assays (Luciano-Montalvo and Meléndez 2009). It is known that STAT-1 activates HIV-1 replication, but the high levels of tyrosine phosphorylation (PY) have been associated with HIV-1 inhibitory activity (Chang et al. 2002). Recent studies at our laboratories show a greater expression of STAT-1 PY in PM than in MDM (Luciano-Montalvo and Meléndez 2009). However, there are conflicting reports regarding STAT-1 phosphorylation and HIV infection. It has been reported that HIV infection in MDM induces an increase in STAT-1PY that starts after 6 days of infection (Magnani et al. 2003). However, recent data of our laboratory using monoclonal antibodies to increase specificity showed very low levels of STAT-1PY in MDM until 12 days after infection and higher levels in HIV-infected PM than in HIV-infected MDM (Luciano-Montalvo and Meléndez 2009). The low levels of cystatin B associated with high levels of STAT-1PY in placental macrophages suggest a mechanism for restriction of HIV replication with an activation of a tyrosine kinase that promotes STAT-1PY. Since STAT-1PY701 induces interferon regulatory factor, this results in decreased replication of HIV-1 by interfering with its long terminal repeat-driven replication (Luciano-Montalvo and Meléndez 2009). Modulation of IFN response was also observed in microarray studies of 2and 7-day infected MDM with a shift from elevated to decreased IFN $\alpha / \beta$ responses in HIV-infected MDMs (Brown et al. 2008). Recent immunoprecipitation studies in HIVinfected macrophages followed by LC/MS/MS studies and luciferase assays has revealed possible mechanisms of cystatin B interacting proteins in the inhibition of IFN responses (Rivera et al. 2010). Indeed, other IFN response 
Table 5 Intracellular and secreted proteins associated with HIV restriction in Placental Macrophages as compared with MDM

\begin{tabular}{|c|c|c|c|c|c|c|c|}
\hline \multirow[t]{2}{*}{ Protein name } & \multicolumn{4}{|c|}{$\begin{array}{l}\text { Total peptides detected } \\
\text { in sequencing }\end{array}$} & \multicolumn{2}{|c|}{$\begin{array}{l}\text { Peak intensity in SELDI-TOF } \\
\text { compared with MDM }\end{array}$} & \multirow[t]{2}{*}{ Reference } \\
\hline & MDM & PM & MDM HIV & PM HIV & PM & PM HIV & \\
\hline \multicolumn{8}{|l|}{ From whole cells lysates: } \\
\hline Cytoskeletal 14 -like protein & ND & 2 & ND & ND & $\downarrow$ & $\downarrow$ & Luciano-Montalvo et al. 2008 \\
\hline SH3 glutamic acid rich like protein 3 & 2 & ND & ND & ND & & $\downarrow$ & Luciano-Montalvo et al. 2008 \\
\hline Protein S-100 A8 (calgranulin A) & ND & ND & 2 & ND & $\downarrow$ & $\downarrow$ & Luciano-Montalvo et al. 2008 \\
\hline $10 \mathrm{kDa}$ heat shock protein & 2 & 2 & 2 & 2 & $\downarrow$ & $\downarrow$ & Luciano-Montalvo et al. 2008 \\
\hline Cystatin B & 4 & 2 & 4 & 3 & $\downarrow$ & $\downarrow$ & Luciano-Montalvo et al. 2008 \\
\hline Cytochrome C & 2 & 2 & 2 & 2 & $\downarrow$ & $\downarrow$ & Luciano-Montalvo et al. 2008 \\
\hline SH3 glutamic acid rich like protein 1 & 4 & ND & 4 & ND & $\uparrow$ & $\uparrow$ & Luciano-Montalvo et al. 2008 \\
\hline Myotrophin & ND & 2 & 2 & ND & $\uparrow$ & $\uparrow$ & Luciano-Montalvo et al. 2008 \\
\hline Protein S-100 A8 (calgranulin B) & ND & ND & 2 & 2 & $\uparrow$ & $\uparrow$ & Luciano-Montalvo et al. 2008 \\
\hline Galectin-1 & ND & ND & 2 & ND & $\uparrow$ & $\uparrow$ & Luciano-Montalvo et al. 2008 \\
\hline Profilin & 5 & 6 & 5 & 5 & $\downarrow$ & $\downarrow$ & Luciano-Montalvo et al. 2008 \\
\hline Superoxide dismutase $\mathrm{CuZn}$ & 2 & ND & ND & 2 & $\uparrow$ & $\uparrow$ & Luciano-Montalvo et al. 2008 \\
\hline \multicolumn{8}{|l|}{ From macrophage secretome: } \\
\hline Fatty acid-binding protein 3 & 2 & 1 & NE & $\mathrm{NE}$ & $\uparrow$ & $\mathrm{NE}$ & Garcia et al. 2009 \\
\hline FKBP12 & & & $\mathrm{NE}$ & $\mathrm{NE}$ & $\uparrow$ & $\mathrm{NE}$ & Garcia et al. 2009 \\
\hline Thioredoxin & 2 & 2 & NE & $\mathrm{NE}$ & $\uparrow$ & $\mathrm{NE}$ & Garcia et al. 2009 \\
\hline Peroxiredoxin 5 & ND & 3 & $\mathrm{NE}$ & $\mathrm{NE}$ & $\uparrow$ & $\mathrm{NE}$ & Garcia et al. 2009 \\
\hline
\end{tabular}

$P M$ placental macrophages, $N D$ not determined, $N E$ not examined

inhibitors have also been reported in studies from SIVinfected macaques (Akhtar et al. 2010). However, upregulation of an interferon-stimulated gene 15, an ubiquitin-like protein involved in interferon-mediated antiviral immunity was recently found in Treg-MDM co-cultures with novel proteomic approaches (ITRAQ) indicating a modulation of IFN responses in MDM by T-regs (Huang et al. 2010). Taken together, these proteomics studies have deepened our current understanding of pathways in HIV-infected MDM, and thus could provide better targets for elimination of HIV reservoirs in the future.

Proteomics platforms were also used to identify secreted factors that might be associated with HIV-1 restriction in PM and HIV persistence in MDM. The screening of the secretome using SELDI-TOF followed by LC/MS/MS confirmed that $\mathrm{PM}$ and MDM were secreting different proteins (Garcia et al. 2009). After sequencing and identification, several proteins were validated for differential expression in PM and MDM by Western blot analysis. This study reported that peroxiredoxin 5 is significantly more abundant in PM than in MDM supernatants. This protein is important in the cellular antioxidant mechanisms, and other members of its family have shown antiviral activity. Furthermore, peroxiredoxin 5 has been found to negatively regulate TNF- $\alpha$ signaling, and so it could also suppress NF-KB activity and HIV-1 replication in PM (Garcia et al. 2009). Cystatin B was also found to be significantly more abundant in MDM than in PM supernatants (Garcia et al. 2009). These data confirmed the higher levels of cystatin B in MDM cell lysates reported by Luciano-Montalvo et al. (2008). We suggested that high expression of peroxiredoxin 5 could be one of the mechanisms by which HIV-1 replicates inefficiently in placental macrophages, whereas low expression of cystatin B could impair their capacity to replicate HIV-1, but the mechanisms remain under investigation (Luciano-Montalvo et al. 2008; LucianoMontalvo and Meléndez 2009; Garcia et al. 2009). Interestingly, peroxiredoxin 5 was one of the proteins identified as downregulated in recent proteomics studies of monocytes derived from women with HAND, a finding that suggests chronically activated monocytes act as a Trojan horse that carries HIV to the brain (Kraft-Terry et al. 2010).

Taken together, proteomics approaches have been used to elucidate the proteome and secretome of tissue macrophages in order to determine how these new players interact with proteins related to HIV-1 replication.

\section{Proteomics of monocytes, macrophages, and microglia in HIV dementia}

After HIV-1 enters the CNS, either as a cell-free virus or in infected macrophages, several signaling pathways are 
activated with the release of inflammatory products, chemokines, and neurotoxins (cellular and viral) that attract other cells to the site of infection, resulting in an increase of intra neuronal calcium and subsequently producing neuronal death (Gendelman et al. 1997; Li et al. 2005; Persidsky et al. 1997). This damage results in psychomotor slowing, memory impairment, and brain atrophy (Anderson et al. 2002). In fact, apoptosis of neurons and astrocytes has been detected in brain tissue autopsies from AIDS patients with HAD (Adle-Biassette et al. 1995).

The communication between the nervous and the peripheral immune systems is an important pathway for activation of macrophages during HAD (Ballabh et al. 2004). The response of the CNS to systemic immune challenge results in brain inflammation caused by infected monocytes/macrophages trafficking into the brain from the periphery, producing disruption of the BBB by oxidative proteins (Gonzalez-Scarano and Martin-Garcia 2005).

Luo et al. (2003) identified several protein peak differences between uninfected and HIV-1-infected MDM linked to the pathogenesis of HAD. We identified 177 protein peaks in lysates of HIV-1-infected MDM from Hispanic patients receiving highly active antiretroviral treatment, among which 38 peaks were related to cognitive impairment (Table 2). These data supported the hypothesis of the emergence of a monocyte subset in patients at the onset of dementia. Afterwards, our collaborators examined the proteome of HIV-infected MDM (Carlson et al. 2004). They used SELDI-TOF to detect 58 differentially expressed proteins in MDM after in vitro infection with HIV-1 ADA, a macrophage tropic R5 virus (Gendelman et al. 1988) (Table 3). Microsequencing of these proteins by LC/MS/ MS permitted identification of important cellular proteins such as B-actin, annexin A5, vimentin, L-plastin, and desmoyokin, in addition to viral proteins such as gp120 and vif (Table 3). The fact that many of these proteins are related to changes in cellular structure and functions supports the hypothesis of alterations in the cell after HIV infection (Carlson et al. 2004). Sun et al. (2004) used the same approach to compare profiles of secreted MDM proteins from HIV-seropositive individuals with normal cognition, HAD, and HIV-negative controls. This group found a decrease in secretion of lysozyme in MDM supernatants from individuals with HAD, thus demonstrating alterations in cell function as a consequence of HAD (Table 2).

The SELDI-TOF approach was used initially to profile the defining characteristics of disease progression (Luo et al. 2003; Wojna et al. 2004). However, the spectra developed with this approach were not comparable among instruments at various institutions and did not allow us to identify the proteins that were differentially expressed. Therefore, identification of the proteome was the next approach to be used, first by 1D gel electrophoresis and sequencing by LC/MS/MS. Using this approach, studies aimed at deciphering the effect of HIV variants from patients with cognitive impairment on the macrophage proteome, our group identified 20 proteins related to apoptosis, chemotaxis, inflammation, and redox metabolism (Toro-Nieves et al. 2009; Table 3). Some of the identified proteins in HIV-infected MDM, including ferritin, ubiquitin, and apoptosis-related proteins, have been identified in macrophage-induced inflammation (Xue et al. 2008). These studies showed that the macrophage's proteome can change depending on the infecting viral strain by stimulating an inflammatory and pro-apoptotic phenotype. The mechanisms by which these viruses affect the macrophage proteome are currently being investigated.

After HIV-1 infects macrophages, several signals are activated causing morphological and functional changes to the cell (Chertova et al. 2006; Ciborowski et al. 2007; Kadiu et al. 2007; Lee et al. 2003). By using SELDI-TOF, LC/MS/MS, and Western blots, culture fluids derived from in vitro HIV-1-infected MDM identified 15 differentially expressed proteins, including cytoskeletal proteins (Kadiu et al. 2007; Table 3). Their findings demonstrated HIV-1 can drive the cell to a permissive state for viral replication or can enhance phagocytosis and intracellular microbial killing. This group subsequently demonstrated how HIV-1 transforms the monocyte plasma membrane proteome by their use of cell surface labeling with fluorescent dyes followed by 2D DIGE and LC/MS/MS analysis (Kadiu et al. 2009). They found that $53 \%$ of HIV-1-induced proteins were associated with the plasma membrane, cellular activation, and oxidative stress, which are processes related to HAD neuropathogenesis (Table 3). Using a similar proteomics platform, Ricardo-Dukelow et al. (2007) established how HIV-1-infected MDM induced upregulation of 161 human brain microvascular endothelial cell proteins that are related to important cellular processes such as metabolism, transport, structural changes, and regulation. Their findings support the role of HIV-1-infected MDM in BBB dysfunction, which contribute to HAD (Table 3).

Despite all the confirmed information about the interactions between HIV-1 and macrophages, the exact pathways of macrophage activation after HIV-1 infection remain incompletely understood. Using proteomics, other studies have shown that the macrophage secretome is affected by HIV-1 infection (Ciborowski et al. 2007) where cystatins B and $\mathrm{C}$, L-plastin, superoxide dismutase, and $\alpha$-enolase were identified preferentially from HIV-infected cells (Table 3 ).

Taken together, proteomics studies clearly demonstrate the effects of HIV-1 on the macrophage activation, structure, and function. These results are not distant from microarray studies where an inflammatory M1 HIV macrophage predominates following HIV infection with 
activation of apoptotic signaling that is modulated after time in culture (Brown et al. 2008).

For studies of CD14+ monocytes from HIV infected Hispanic women with HAND, our laboratory applied a SELDI-TOF, 2D DIGE, and LC/MS/MS proteomics. Initial SELDI-TOF studies, compared protein profiles from CD14+ monocytes isolated from 35 individuals-eight normal cognition $(\mathrm{N}), 11$ asymptomatic $(\mathrm{A})$ as defined by substandard neuropsychological results and early symptoms of $\mathrm{CI}$, three minor cognitive motor disorder (MCMD), and $13 \mathrm{HAD}$. Interestingly, three peaks$5,656,5,976$, and $6,705 \mathrm{~m} / \mathrm{z}$-were shown to be significant (adjusted $p$ value $\leq 0.1$ ) in terms of the intensity differences in all four group comparisons (Fig. 1). Additional protein peaks $(n=41)$ were found differentially expressed between individual groups (data not shown). These results demonstrated that $\mathrm{CD} 14+$ monocytes from the HAND group, starting at the early stage, expressed predominantly decreased proteins than did those from patients with normal cognition. Subsequently, to ascertain that there were proteins differentially expressed in women with HAND, we performed 2-DIGE analyses followed by LC/MS/MS and flow cytometry validation of the proteins found between the two extreme groups: normal cognition and HAD (Kraft-Terry et al. 2010). Our findings showed

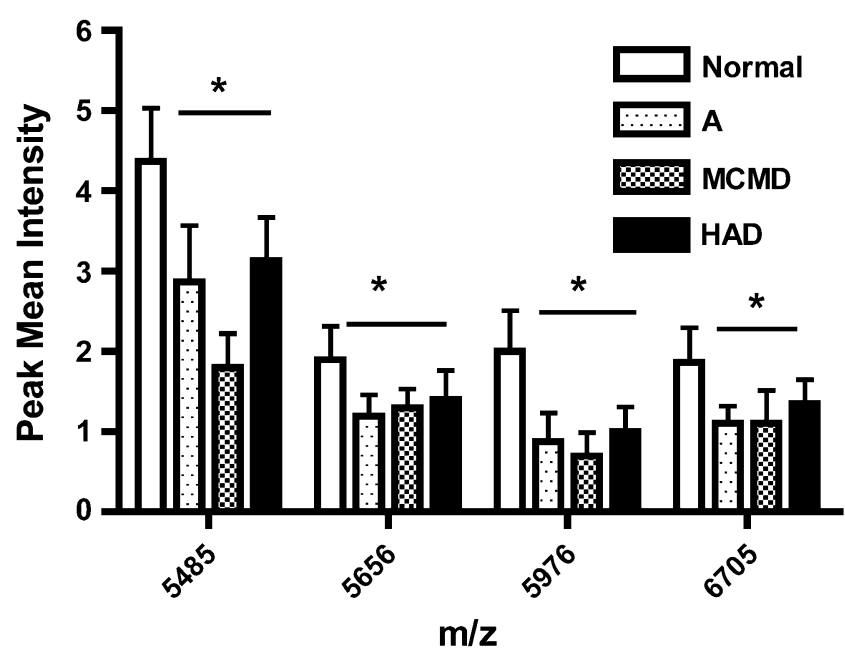

Fig. 1 SELDI-TOF protein peaks with significant differences in monocytes from HIV-seropositive women with HAND. CD14+ monocytes from $35 \mathrm{HIV}$-seropositive women (8 normal cognition (NC), 11 asymptomatics (A), 3 minor cognitive and motor disorder (MCMD), and 12 (HAD) were profiled by SELDI-TOF and analyzed by ANOVA and GEE. Significant decrease in the intensity of three protein peaks was found in CD14+ monocytes from HIV-seropositive women in groups $\mathrm{A}, \mathrm{MCMD}$, and $\mathrm{HAD}$ as compared with the group having normal cognition (adjusted $p$ value $\leq 0.1$ ). SELDI-TOF spectra of were compared using ANOVA and generalized estimating equation (GEE) statistics. The concept of false discovery rate was applied to correct the multiple comparisons (Benjamini and Hochberg 1995; Storey and Tibshirani 2003), and the most significant differences were selected according to the $10 \%$ cut-off value
SOD, thioxiredoxin, and peroxiredoxin antioxidant proteins as downregulated in monocytes from patients with HAD (Kraft-Terry et al. 2010; Table 2).

Wang et al. (2008) established a proteomic modeling for crosstalk between HIV-1-infected microglia and astrocytes. Using 2D DIGE, Western blot, and LC/MS/MS they detected changes in the microglial cytoskeleton and alterations in the microglial-astrocyte communication. These observations provided unique insights into glial crosstalk and how it is related to HAD.

In the neuroAIDS field, proteomics approaches have also been used for studying the CSF (Yuan and Desiderio 2005; Laspiur et al. 2007; Rozek et al. 2007). Currently, some of the proteins uncovered in HAND that are common to CSF and HIV-infected MDM are subject to functional studies including cystatins, cathepsins, and SOD (Kadiu et al. 2009; Luciano-Montalvo and Meléndez 2009; Rodriguez-Franco et al. 2010; Rivera et al. 2010). These proteomics studies have helped to elucidate important mechanisms in HIV infection, MDM activation, and disease.

\section{Conclusion and future directions}

This review provides an overview of the knowledge about the function of HIV-infected monocytes/macrophages that has been obtained by using various proteomics approaches. It includes studies from the pre-proteomics and postproteomics eras with a detailed description of the proteomics approaches used (Table 1). These methods have helped to identify the differences in proteins that are resolved in a gel electrophoresis approach and, if coupled to fluorescence tagged markers as in 2D DIGE, have helped to quantify their relative abundance in experimental and control samples.

Proteomic studies applied to the discovery of potential biomarkers from ex vivo studies of macrophage proteins derived from patients with HIV-associated neurocognitive dysfunction have been cumbersome and provide few protein candidates because of the limited number of MDM available for gel-based studies. However, these studies have yielded promising candidates and spearheaded the discovery of new disease mechanisms (Table 2).

Proteomic studies applied to in vitro studies of HIVinfected macrophages have been facilitated by an abundance of macrophages from leukopheresis and elutriation provided by Dr. Gendelman's laboratory (Table 3). These studies have revealed the presence of proteins related to inflammation, oxidative stress, apoptosis, cytoskeleton, and signaling pathways. Many of these proteins are being tested in functional studies and could be potential avenues for increasing our understanding of the biology of HIV to eventually eradicate cellular reservoirs and add new targets for therapies and vaccines. 
Novel system biology and proteomics approaches for quantitative proteomics have been reviewed (Table 4). These methods will likely lead to more complex proteomes of HIV-infected MDM to facilitate the discovery of increased number of biomarkers for diagnosis and therapies against HAND and other infectious and neuroinflammatory diseases, which will further the understanding of the role of macrophages in different diseases.

Acknowledgments This work was supported in part by grants from the National Institutes of Health to Dr. Melendez (R01MH083516, U54NS4301, GM08224, G12RR03051) and to Krystal Colon and Eillen Rodriguez-Franco (GM061838) and by institutional funds. We thank Alexandra Cabán for her help in manuscript writing, sponsored by Melendez R01MH083516.

Conflict of interest disclosure The authors report no conflicts of interest.

Open Access This article is distributed under the terms of the Creative Commons Attribution Noncommercial License which permits any noncommercial use, distribution, and reproduction in any medium, provided the original author(s) and source are credited.

\section{References}

Adle-Biassette H, Levy Y, Colombel M, Poron F, Natchev S, Keohane C, Gray F (1995) Neuronal apoptosis in HIV infection in adults. Neuropathol Appl Neurobiol 21:218-227

Agasalda MA, Wojna V, Melendez L, Shiramizu B (2010) CSF monocyte reservoirs in HAND development and the possible role of insertional mutagenesis. J Neurovirol 16S1:2

Akhtar LN, Qin H, Muldowney MT, Yanagisawa LL, Kutsch O, Clements JE, Benveniste EN (2010) Suppressor of cytokine signaling 3 inhibits antiviral IFN-beta signaling to enhance HIV-1 replication in macrophages. J Immunol 185:2393-2404

Alexaki A, Wigdahl B (2008) HIV-1 infection of bone marrow hematopoietic progenitor cells and their role in trafficking and viral dissemination. PLoS Pathog 4:e1000215

Alkhatib G, Combadiere C, Broder CC, Feng Y, Kennedy PE, Murphy PM, Berger EA (1996) CC CKR5: a RANTES, MIP-1alpha, MIP-1 beta receptor as a fusion cofactor for macrophage-tropic HIV-1. Science 272:1955-1958

Ancuta P, Liu KY, Misra V, Wacleche VS, Gosselin A, Zhou X, Gabuzda D (2009) Transcriptional profiling reveals developmental relationship and distinct biological functions of CD16+ and CD16monocyte subsets. BMC Genomics 10:403

Anderson E, Zink W, Xiong H, Gendelman HE (2002) HIV-1associated dementia: a metabolic encephalopathy perpetrated by virus-infected and immune-competent mononuclear phagocytes. J Acquir Immune Defic Syndr 31(Suppl 2):S43-S54

Bachis A, Cruz MI, Mocchetti I (2010) M-tropic HIV envelope protein gp120 exhibits a different neuropathological profile than T-tropic gp120 in rat striatum. Eur J Neurosci 32:570-578

Bailey JR, Sedaghat AR, Kieffer T, Brennan T, Lee PK, Wind-Rotolo M, Haggerty CM, Kamireddi AR, Liu Y, Lee J, Persaud D, Gallant JE, Cofrancesco J Jr, Quinn TC, Wilke CO, Ray SC, Siliciano JD, Nettles RE, Siliciano RF (2006) Residual human immunodeficiency virus type 1 viremia in some patients on antiretroviral therapy is dominated by a small number of invariant clones rarely found in circulating CD4+ T cells. J Virol 80:6441-6457

Ballabh P, Braun A, Nedergaard M (2004) The blood-brain barrier: an overview: structure, regulation, and clinical implications. Neurobiol Dis 16:1-13

Banks WA, Freed EO, Wolf KM, Robinson SM, Franko M, Kumar VB (2001) Transport of human immunodeficiency virus type 1 pseudoviruses across the blood-brain barrier: role of envelope proteins and adsorptive endocytosis. J Virol 75:4681-4691

Benjamini Y and Hochberg Y (1995) Controlling the false discovery rate: A practical and powerful approach to multiple testing. $\mathrm{J}$ Royal Stat Soc. 57:289-300.

Berger EA, Doms RW, Fenyo EM, Krober BT, Littman DR, Moore JP, Sattentau QJ, Schuitemaker H, Sodroski J, Weiss RA (1998) A new classififcation for HIV-1. Nature 391(6664):240

Bertone P, Snyder M (2005) Advances in functional protein microarray technology. FEBS J 272:5400-5411.

Bezzi P, Domercq M, Brambilla L, Galli R, Schols D, De Clercq E, Vescovi A, Bagetta G, Kollias G, Meldolesi J, Volterra A (2001) CXCR4-activated astrocyte glutamate release via TNFalpha: amplification by microglia triggers neurotoxicity. Nat Neurosci 4:702-710

Bieniasz PD, Cullen BR (1998) Chemokine receptors and human immunodeficiency virus infection. Front Biosci 3:d44-d58

Brown JN, Kohler JJ, Coberley CR, Sleasman JW, Goodenow MM (2008) HIV-1 activates macrophages independent of Toll-like receptors. PLoS ONE 3:e3664

Casado-Vela J, Martínez-Esteso MJ, Rodriguez E, Borrás E, Elortza F, Bru-Martínez R (2010) iTRAQ-based quantitative analysis of protein mixtures with large fold change and dynamic range. Proteomics 10:343-347

Carlson KA, Ciborowski P, Schellpeper CN, Biskup TM, Shen RF, Luo X, Destache CJ, Gendelman HE (2004) Proteomic fingerprinting of HIV-1-infected human monocyte-derived macrophages: a preliminary report. J Neuroimmunol 147:35-42

Chang TL, Mosoian A, Pine R, Klotman ME, Moore JP (2002) A soluble factor(s) secreted from CD8(+) T lymphocytes inhibits human immunodeficiency virus type 1 replication through STAT1 activation. J Virol 76:569-581

Charboneau L, Tory H, Chen T, Winters M, Petricoin EF 3rd, Liotta LA, Paweletz CP (2002) Utility of reverse phase protein arrays: applications to signalling pathways and human body arrays. Brief Funct Genomic Proteomic 1:305-315

Cheng-Mayer C, Homsy J, Evans LA, Levy JA (1988) Identification of human immunodeficiency virus subtypes with distinct patterns of sensitivity to serum neutralization. Proc Natl Acad Sci USA $85: 2815-2819$

Chertova E, Chertov O, Coren LV, Roser JD, Trubey CM, Bess JW Jr, Sowder RC 2nd, Barsov E, Hood BL, Fisher RJ, Nagashima K, Conrads TP, Veenstra TD, Lifson JD, Ott DE (2006) Proteomic and biochemical analysis of purified human immunodeficiency virus type 1 produced from infected monocyte-derived macrophages. J Virol 80:9039-9052

Chun TW, Chadwick K, Margolick J, Siliciano RF (1997) Differential susceptibility of naive and memory CD4+ T cells to the cytopathic effects of infection with human immunodeficiency virus type 1 strain LAI. J Virol 71:4436-4444

Cicala C, Arthos J, Selig SM, Dennis G Jr, Hosack DA, Van Ryk D, Spangler ML, Steenbeke TD, Khazanie P, Gupta N, Yang J, Daucher M, Lempicki RA, Fauci AS (2002) HIV envelope induces a cascade of cell signals in non-proliferating target cells that favor virus replication. Proc Natl Acad Sci USA 99:9380-9385

Ciborowski P, Kadiu I, Rozek W, Smith L, Bernhardt K, Fladseth M, Ricardo-Dukelow M, Gendelman HE (2007) Investigating the human immunodeficiency virus type 1-infected monocytederived macrophage secretome. Virology 363:198-209 
Collman R, Hassan NF, Walker R, Godfrey B, Cutilli J, Hasting JC, Friedman H, Douglas SD, Nathanson N (1989) Infection of monocyte-derived macrophages with human immunodeficiency virus type 1 (HIV-1). Monocyte-tropic and lymphocyte-tropic strains of HIV-1 show distinctive patterns of replication in a panel of cell types. J Exp Med 170:1149-1163

Crowe S, Zhu T, Muller WA (2003) The contribution of monocyte infection and trafficking to viral persistence, and maintenance of the viral reservoir in HIV infection. J Leukoc Biol 74:635-641

Davis LE, Hjelle BL, Miller VE, Palmer DL, Llewellyn AL, Merlin TL, Young SA, Mills RG, Wachsman W, Wiley CA (1992) Early viral brain invasion in iatrogenic human immunodeficiency virus infection. Neurology 42:1736-1739

Dalle-Donne I, Aldini G, Carini M, Colombo R, Rossi R, Milzani A (2006) Protein carbonylation, cellular dysfunction, and disease progression. J Cell Mol Med 10:389-406

Del Corno M, Liu QH, Schols D, de Clercq E, Gessani S, Freedman BD, Collman RG (2001) HIV-1 gp120 and chemokine activation of Pyk2 and mitogen-activated protein kinases in primary macrophages mediated by calcium-dependent, pertussis toxininsensitive chemokine receptor signaling. Blood 98:2909-2916

Deng H, Liu R, Ellmeier W, Choe S, Unutmaz D, Burkhart M, Di Marzio P, Marmon S, Sutton RE, Hill CM, Davis CB, Peiper SC, Schall TJ, Littman TR, Landau NR (1996) Identification of a major co-receptor for primary isolates of HIV-1. Nature 381:661-666

Doranz BJ, Rucker J, Yi Y, Smyth RJ, Samson M, Peiper SC, Parmentier M, Collman RG, Doms RW (1996) A dual-tropic primary HIV-1 isolate that uses fusin and the beta-chemokine receptors CKR-5, CKR-3, and CKR-2b as fusion cofactors. Cell $85: 1149-1158$

Dreyer EB, Lipton SA (1995) The coat protein gp120 of HIV-1 inhibits astrocyte uptake of excitatory amino acids via macrophage arachidonic acid. Eur J Neurosci 7:2502-2507

Duenas-Decamp MJ, Peters PJ, Repik A, Musich T, Gonzalez-Perez MP, Caron C, Brown R, Ball J, Clapham PR (2010) Variation in the biological properties of the HIV-1 R5 envelope: implications of envelope structure, transmission and pathogenesis. Future Virol 5(4):435-451

Dupont A, Tokarski C, Dekeyzer O, Guihot AL, Amouyel P, Rolando C, Pinet F (2004) Two-dimensional maps and databases of the human macrophage proteome and secretome. Proteomics 4:1761-1778

Ellery PJ, Tippett E, Chiu YL, Paukovics G, Cameron PU, Solomon A, Lewin SR, Gorry PR, Jaworowski A, Greene WC, Sonza S, Crowe SM (2007) The CD16+ monocyte subset is more permissive to infection and preferentially harbors HIV-1 in vivo. J Immunol 178:6581-6589

Embretson J, Zupancic M, Beneke J, Till M, Wolinsky S, Ribas JL, Burke A, Haase AT (1993) Analysis of human immunodeficiency virus-infected tissues by amplification and in situ hybridization reveals latent and permissive infections at single-cell resolution. Nature 362:359-362

Fear WR, Kesson AM, Naif H, Lynch GW, Cunningham AL (1998) Differential tropism and chemokine receptor expression of human immunodeficiency virus type 1 in neonatal monocytes, monocyte-derived macrophages, and placental macrophages. J Virol 72:1334-1344

Finzi D, Hermankova M, Pierson T, Carruth LM, Buck C, Chaisson RE, Quinn TC, Chadwick K, Margolick J, Brookmeyer R, Gallant J, Markowitz M, Ho DD, Richman DD, Siliciano RF (1997) Identification of a reservoir for HIV-1 in patients on highly active antiretroviral therapy. Science 278:1295-1300

Fischer-Smith T, Bell C, Croul S, Lewis M, Rappaport J (2008) Monocyte/macrophages trafficking in acquired immunodeficiency syndrome encephalitis: lessons from human and nonhuman primate studies. J Neurovirol 14(4):318-326
Fischer-Smith T, Croul S, Sverstiuk AE, Capini C, L'Heureux D, Régulier EG, Richardson MW, Amini S, Morgello S, Khalili K, Rappaport J (2001) CNS invasion by CD14+/CD16+ peripheral blood-derived monocytes in HIV dementia: perivascular accumulation and reservoir of HIV infection. J Neurovirol 7:528-541

Fischer-Smith T, Rappaport J (2005) Evolving paradigms in the pathogenesis of HIV-1-associated dementia. Expert Rev Mol Med 7:1-26

Garcia K, Garcia V, Perez Laspiur J, Duan F, Melendez LM (2009) Characterization of the placental macrophage secretome: implications for antiviral activity. Placenta 30:149-155

Gartner S (2000) HIV infection and dementia. Science 287 (5453):602-604

Gendelman H, Anderson E, Melendez L, Zheng J (2006) Chemokines and their receptors in HIV-1 neuropathogenesis, In Vivo Models of HIV Disease and Control. Eds H. Friedman, S. Specter, and M. Bendinelli. Springer. pp 45-80

Gendelman HE, Baca LM, Husayni H, Turpin JA, Skillman D, Katler DC, Burke DS, Tramont EC, Meltzer MS (1990) MacrophageHIV interaction: viral isolation and target cell tropism. AIDS 4:221-228

Gendelman HE, Orenstein JM, Martin MA, Ferrua C, Mitra R et al (1988) Efficient isolation and propagation of human immunodeficiency virus on recombinant colony-stimulating factor 1-treated monocytes. J Exp Med 167:1428-1441

Gendelman HE, Persidsky Y, Ghorpade A, Limoges J, Stins M et al (1997) The neuropathogenesis of the AIDS dementia complex. AIDS 11(Suppl A):S35-S45

Genis P, Jett M, Bernton EW, Boyle T, Gelbard HA, Dzenko K, Keane RW, Resnick L, Mizrachi Y, Volsky DJ (1992) Cytokines and arachidonic metabolites produced during human immunodeficiency virus (HIV)-infected macrophage-astroglia interactions: implications for the neuropathogenesis of HIV disease. J Exp Med 176:1703-1718

Gevaert K, Vandekerckhove J (2000) Protein identification methods in proteomics. Electrophoresis 21(6):1145-1154

Giulian D, Vaca K, Noonan CA (1990) Secretion of neurotoxins by mononuclear phagocytes infected with HIV-1. Science 250:1593-1596

Giri MS, Nebozyhn M, Raymond A, Gekonge B, Hancock A, Creer S, Nicols C, Yousef M, Foulkes AS, Mounzer K, Shull J, Silvestri G, Kostman J, Collman RG, Showe L, Montaner LJ (2009) Circulating monocytes in HIV-1-infected viremic subjects exhibit an antiapoptosis gene signature and virus- and host-mediated apoptosis resistance. J Immunol 182:4459-4470

Go EP, Chang Q, Liao HX, Sutherland LL, Alam SM, Haynes BF, Desaire H (2009) Glycosylation site-specific analysis of clade C HIV-1 envelope proteins. J Proteome Res 8:4231-4242

Gonzalez-Scarano F, Baltuch G (1999) Microglia as mediators of inflammatory and degenerative diseases. Annu Rev Neurosci $22: 219-240$

Gonzalez-Scarano F, Martin-Garcia J (2005) The neuropathogenesis of AIDS. Nat Rev Immunol 5:69-81

Goodenow MM, Collman RG (2006) HIV-1 co receptor preference is distinct from target cell tropism: a dual-parameter nomenclature to define viral phenotypes. J Leukoc Biol 80:965-972

Gorry PR, Churchill M, Crowe SM, Cunningham AL, Gabuzda D (2005) Pathogenesis of macrophage tropic HIV-1. Curr HIV Res 3(1):53-60

Graham DR, Mitsak MJ, Elliott ST, Chen D, Whelan SA, Hart GW, Van Eyk JE (2008) Two-dimensional gel-based approaches for the assessment of N-Linked and O-GlcNAc glycosylation in human and simian immunodeficiency viruses. Proteomics 8:4919-4930

Hickey WF, Kimura H (1988) Perivascular microglial cells of the $\mathrm{CNS}$ are bone marrow-derived and present antigen in vivo. Science 239:290-292 
Hladik F, Lentz G, Akridge RE, Peterson G, Kelley H, McElroy A, McElrath MJ (1999) Dendritic cell-T cell interactions support coreceptor-independent human immonudeficiency virus type 1 transmission in the human genital tract. J Virol 73(7):5833-5842

Huang X, Stone DK, Yu F, Zeng Y, Gendelman HE (2010) Functional proteomic analysis for regulatory $\mathrm{T}$ cell surveillance of the HIV1-infected macrophage. J Proteome Res (in press)

Ibarrola N, Kalume DE, Gronborg M, Iwahori A, Pandey A (2003) A proteomic approach for quantitation of phosphorylation using stable isotope labeling in cell culture. Anal Chem 75:6043-6049

Jaworski A, Smith CL, Burden SJ (2007) GA-binding protein is dispensable for neuromuscular synapse formation and synapsespecific gene expression. Mol Cell Biol 27:5040-5046

Jiang ZG, Piggee C, Heyes MP, Murphy C, Quearry B, Bauer M, Zheng J, Gendelman HE, Markey SP (2001) Glutamate is a mediator of neurotoxicity in secretions of activated HIV-1infected macrophages. J Neuroimmunol 117:97-107

Jemal M, Xia YQ (2006) LC-MS development strategies for quantitative bioanalysis. Curr Drug Metab 7:491-502

Jorge I, Casas EM, Villar M, Ortega-Pérez I, López-Ferrer D, Martínez-Ruiz A, Carrera M, Marina A, Martínez P, Serrano H, Cañas B, Were F, Gallardo JM, Lamas S, Redondo JM, GarcíaDorado D, Vázquez J (2007) High-sensitivity analysis of specific peptides in complex samples by selected MS/MS ion monitoring and linear ion trap mass spectrometry: application to biological studies. J Mass Spectrom 42:1391-1403

Jorge I, Navarro P, Martínez-Acedo P, Núñez E, Serrano H, Alfranca A, Redondo JM, Vázquez J (2009) Statistical model to analyze quantitative proteomics data obtained by ${ }^{18} \mathrm{O} /{ }^{16} \mathrm{O}$ labeling and linear ion trap mass spectrometry: application to the study of vascular endothelial growth factor-induced angiogenesis in endothelial cells. Mol Cell Proteomics 8:1130-1149

Kadiu I, Ricardo-Dukelow M, Ciborowski P, Gendelman HE (2007) Cytoskeletal protein transformation in HIV-1-infected macrophage giant cells. J Immunol 178:6404-6415

Kadiu I, Wang T, Schlautman JD, Dubrovsky L, Ciborowski P et al (2009) HIV-1 transforms the monocyte plasma membrane proteome. Cell Immunol 258:44-58

Kaul M, Garden GA, Lipton SA (2001) Pathways to neuronal injury and apoptosis in HIV-associated dementia. Nature 410:988-994

Keele BF, Giorgi EE, Salazar-Gonzalez JF, Decker JM, Pham KT, Salazar MG, Sun C, Grayson T, Wang S, Li H, Wei X, Jiang C, Kirchherr JL, Gao F, Anderson JA, Ping LH, Swanstrom R, Tomaras GD, Blattner WA, Goepfert PA, Kilby JM, Saag MS, Delwart EL, Busch MP, Cohen MS, Montefiori DC, Haynes BF, Gaschen B, Athreya GS, Lee HY, Wood N, Seoighe C, Perelson AS, Bhattacharya T, Korber BT, Hahn BH, Shaw GM (2008) Identification and characterization of transmitted and early founder virus envelopes in primary HIV-1 infection. Proc Natl Acad Sci USA 105:7552-7557

Kesson AM, Fear WR, Kazazi F, Mathijs JM, Chang J et al (1993) Human immunodeficiency virus type 1 infection of human placental macrophages in vitro. J Infect Dis 168:571-579

Kesson AM, Fear WR, Williams L, Chang J, King NJ, Cunningham AL (1994) HIV infection of placental macrophages: their potential role in vertical transmission. J Leukoc Biol 56:241-246

Kim WK, Corey S, Alvarez X, Williams K (2003) Monocyte/ macrophages traffic in HIV and SIV encephalitis. J Leukoc Biol 74(5):650-656

Kim WK, Alvarez X, Fisher J, Bronfin B, Westmoreland S, McLaurin J, Williams K (2006) CD163 identifies perivascular macrophages in normal and viral encephalitic brains and potential precursors to perivascular macrophages in blood. Am J Pathol 168:822-834

Kim WK, Avarez X, Williams K (2005) The role of monocytes and perivascular macrophages in HIV and SIV neuropathogenesis: information from non-human primate models. Neurotox Res $8(1-$ 2): $107-115$

Kota U, Chien KY, Goshe MB (2009) Isotope-labeling and affinity enrichment of phosphopeptides for proteomic analysis using liquid chromatography-tandem mass spectrometry. Meth Mol Biol 564:303-321

Kraft-Terry SD, Stothert AR, Buch S, Gendelman HE (2010) HIV-1 neuroimmunity in the era of antiretroviral therapy. Neurobiol Dis $37: 542-548$

Lambotte O, Taoufik Y, de Goer MG, Wallon C, Goujard C, Delfraissy JF (2000) Detection of infectious HIV in circulating monocytes from patients on prolonged highly active antiretroviral therapy. J Acquir Immune Defic Syndr 23:114-119

Laspiur JP, Anderson ER, Ciborowski P, Wojna V, Rozek W, Duan F, Mayo R, Rodríguez E, Plaud-Valentín M, Rodríguez-Orengo J, Gendelman HE, Meléndez LM (2007) CSF proteomic fingerprints for HIV-associated cognitive impairment. J Neuroimmunol 192:157-170

Lee C, Tomkowicz B, Freedman BD, Collman RG (2005) HIV-1 gp120-induced TNF-\{alpha\} production by primary human macrophages is mediated by phosphatidylinositol-3 (PI-3) kinase and mitogen-activated protein (MAP) kinase pathways. J Leukoc Biol 78:1016-1023

Lee C, Liu QH, Tomkowicz B, Yi Y, Freedman BD, Collman RG (2003) Macrophage activation through CCR5- and CXCR4mediated gp120-elicited signaling pathways. J Leukoc Biol 74 (5):676-682

Le Douce V, Herbein G, Rohr O, Schwartz C (2010) Molecular mechanisms of HIV-1 persistence in the monocyte-macrophage lineage. Retrovirology 7:32

Li H, Bar KJ, Wang S, Decker JM, Chen Y, Sun C, SalazarGonzalez JF, Salazar MG, Learn GH, Morgan CJ, Schumacher JE, Hraber P, Giorgi EE, Bhattacharya T, Korber BT, Perelson AS, Eron JJ, Cohen MS, Hicks CB, Haynes BF, Markowitz M, Keele BF, Hahn BH, Shaw GM (2010) High multiplicity infection by HIV-1 in men who have sex with men. PLoS Pathog 13:e1000890

Li S, Juarez J, Alali M, Dwyer D, Collman R, Cunningham A, Naif HM (1999) Persistent CCR5 utilization and enhanced macrophage tropism by primary blood human immunodeficiency virus type 1 isolates from advanced stages of disease and comparison to tissue-derived isolates. J Virol 73:9741-9755

Li W, Galey D, Mattson MP, Nath A (2005) Molecular and cellular mechanisms of neuronal cell death in HIV dementia. Neurotox Res 8:119-134

Link AJ, Labaer J (2009) In-gel trypsin digest of gel-fractionated proteins. Cold Spring Harb Protoc. doi:10.1101/pdb.prot5110

Luciano-Montalvo C, Ciborowski P, Duan F, Gendelman HE, Melendez LM (2008) Proteomic analyses associate cystatin B with restricted HIV-1 replication in placental macrophages. Placenta 29:1016-1023

Luciano-Montalvo C, Meléndez LM (2009) Cystatin B associates with signal transducer and activator of transcription 1 in monocyte-derived and placental macrophages. Placenta 30:464-467

Luo X, Carlson KA, Wojna V, Mayo R, Biskup TM, Stoner J, Anderson J, Gendelman HE, Meléndez LM (2003) Macrophage proteomic fingerprinting predicts HIV-1-associated cognitive impairment. Neurology 60:1931-1937

Maddon PJ, Dalgleish AG, McDougal JS, Clapham PR, Weiss RA, Axel $\mathrm{R}$ (1986) The T4 gene encodes the AIDS virus receptor and is expressed in the immune system and the brain. Cell 47:333-348

Magnani M, Balestra E, Fraternale A, Aquaro S, Paiardini M et al (2003) Drug-loaded red blood cell-mediated clearance of HIV-1 macrophage reservoir by selective inhibition of STAT1 expression. J Leukoc Biol 74:764-771 
Mann M (2006) Functional and quantitative proteomics using SILAC. Nat Rev Mol Cell Biol 7:952-958

McGann KA, Collman R, Kolson DL, Gonzalez-Scarano F, Coukos G et al (1994) Human immunodeficiency virus type 1 causes productive infection of macrophages in primary placental cell cultures. J Infect Dis 169:746-753

Melendez-Guerrero LM, Nicholson JK, McDougal JS (1990) In vitro infection of monocytes with HIVBa-L. Effect on cell surface expression of CD4, CD14, HLA-DR, and HLA-DQ. AIDS Res Hum Retroviruses 6:731-741

Melendez-Guerrero LM, Nicholson JK, McDougal JS (1991) Infection of human monocytes with HIV-1Ba-L. Effect on accessory cell function for T-cell proliferation in vitro. AIDS Res Hum Retroviruses 7(5):465-474

Meléndez-Guerrero L, Holmes R, Backé E, Polliotti B, Ibegbu C, Lee F, Panigel M, Schwartz D, Huddleston J, Nahmias A (1994) In vitro infection of Hofbauer cells with a monocyte-tropic strain of HIV-1. Placenta 15(Supplement 1):33-45

Melendez J, Garcia V, Sanchez E, Delgado R, Torres G, MelendezGuerrero LM. 2001. Is decreased HIV-1 infectivity of placental macrophages caused by high levels of beta-chemokines? Cell Mol Biol (Noisy-le-grand) 47 Online Pub:OL51-9.

Meltzer MS, Nakamura M, Hansen BD, Turpin JA, Kalter DC, Gendelman HE (1990) Macrophages as susceptible targets for HIV infection, persistent viral reservoirs in tissue, and key immunoregulatory cells that control levels of virus replication and extent of disease. AIDS Res Hum Retroviruses 6:967-971

Morrison RS, Kinoshita JMD, Uo T, Ho JT, McBee JK, Conrads TP, Veenstra TD (2002) Proteomic analysis in the neurosciences. Mol Cell Proteomics 1:553-560

Narayan O, Wolinsky JS, Clements JE, Strandberg JD, Griffin DE, Cork LC (1982) Slow virus replication: the role of macrophages in the persistence and expression of visna viruses of sheep and goats. J Gen Virol 59:345-356

O' Farrell PH (1975) High resolution two-dimensional electrophoresis of proteins. J Biol Chem 250:4007-4021

Pandey A, Mann M (2000) Proteomics to study genes and genomes. Nature 405:837-846

Pathak S, De Souza GA, Salte T, Wiker HG, Asjö B (2009) HIV induces both a down-regulation of IRAK-4 that impairs TLR signalling and an up-regulation of the antibiotic peptide dermcidin in monocytic cells. Scand J Immunol. 70:264-276.

Peluso R, Haase A, Stowring L, Edwards M, Ventura P (1985) A Trojan horse mechanism for the spread of visna virus in monocytes. Virology 147:231-236

Persidsky Y, Buttini M, Limoges J, Bock P, Gendelman HE (1997) An analysis of HIV-1-associated inflammatory products in brain tissue of humans and SCID mice with HIV-1 encephalitis. J Neurovirol 3:401-416

Persidsky Y, Ghorpade A, Rasmussen J, Limoges J, Liu XJ et al (1999) Microglial and astrocyte chemokines regulate monocyte migration through the blood-brain barrier in human immunodeficiency virus-1 encephalitis. Am J Pathol 155:1599-1611

Peters PJ, Duenas-Decamp MJ, Sullivan WM, Clapham PR (2007) Variation of macrophage tropism among HIV-1 R5 envelopes in brain and other tissues. J Neuroimmune Pharmacol 2(1):3241

Pendyala G, Trauger SA, Siuzdak G, Fox HS (2010) Quantitative plasma proteomic profiling identifies the vitamin $\mathrm{E}$ binding protein afamin as a potential pathogenic factor in SIV induced CNS disease. J Proteome Res 9:352-358

Plaud-Valentin M, Delgado R, Garcia V, Zorrilla C, Gandia J, Melendez-Guerrero LM (1999) HIV infection of placental macrophages: effect on the secretion of HIV stimulatory cytokines. Cell Mol Biol Noisy (Noisy-le-grand) 45:423-431
Popovic M, Mellert W, Erfle V, Gartner S (1988) Role of mononuclear phagocytes and accessory cells in human immunodeficiency virus type I infection of the brain. Ann Neurol 23(Suppl):S74-S77

Pulliam L, Gascon R, Stubblebine M, McGuire D, McGrath MS (1997) Unique monocyte subset in patients with AIDS dementia. Lancet 349:692-695

Qian WJ, Petritis BO, Kaushal A, Finnerty CC, Jeschke MG, Monroe ME, Moore RJ, Schepmoes AA, Xiao W, Moldawer LL, Davis RW, Tompkins RG, Herndon DN, Camp DG 2nd, Smith RD, Inflammation and the Host Response to Injury Large Scale Collaborative Research Program (2010) Plasma proteome response to severe burn injury revealed by ${ }^{18} \mathrm{O}$-labeled "universal" reference-based quantitative proteomics. J Proteome Res 3:4779-4789

Qian WJ, Monroe ME, Liu T, Jacobs JM, Anderson GA, Shen Y, Moore RJ, Anderson DJ, Zhang R, Calvano SE, Lowry SF, Xiao W, Moldawer LL, Davis RW, Tompkins RG, Camp DG 2nd, Smith RD, Inflammation and the Host Response to Injury Large Scale Collaborative Research Program (2005) Quantitative proteome analysis of human plasma following in vivo lipopolysaccharide administration using 16O/18O labeling and the accurate mass and time tag approach. Mol Cell Proteomics 4:700-709

Rasheed S, Yan JS, Hussain A, Lai B (2009) Proteomic characterization of HIV-modulated membrane receptors, kinases and signaling proteins involved in novel angiogenic pathways. J Transl Med 7:75

Raymond S, Delobel P, Mavigner M, Cazabat M, Encinas S, Souyris C, Bruel P, Sandres-Sauné K, Marchou B, Massip P, Izopet J (2010) CXCR4-using viruses in plasma and peripheral blood mononuclear cells during primary HIV-1 infection and impact on disease progression. AIDS 24:2305-2312

Ricardo-Dukelow M, Kadiu I, Rozek W, Schlautman J, Persidsky Y, Ciborowski P, Kanmogne GD, Gendelman HE (2007) HIV-1 infected monocyte-derived macrophages affect the human brain microvascular endothelial cell proteome: new insights into bloodbrain barrier dysfunction for HIV-1-associated dementia. J Neuroimmunol 185:37-46

Rivera LE, Perez Laspiur J, Medina F, Munoz-Jordan J, Melendez LM (2010) Inhibition of interferon response by Cystatin B: a proposed mechanism for HIV persistence in macropahge reservoirs. J Neurovirol 16S1:71

Rodriguez-Franco E, Plaud M, Rome R, Skolasky R, Melendez L (2010) Late HIV infection modulates the expression and activity of Cathepsin B, and its inhibitors in macrophages: implications in neuropathogenesis. Retrovirology 7:10

Rozek W, Ricardo-Dukelow M, Holloway S, Gendelman HE, Wojna V, Melendez LM, Ciboroski P (2007) Cerebrospinal fluid proteomic profiling of HIV-1-infected patients with cognitive impairment. J Proteome Res 6(11):4189-4199

Ryckman C, Robichaud GA, Roy J, Cantin R, Tremblay MJ, Tessier PA (2002) HIV-1 transcription and virus production are both accentuated by the proinflammatory myeloid-related proteins in human $\mathrm{CD} 4+\mathrm{T}$ lymphocytes. $\mathrm{J}$ Immunol 169:3307-3313

Shi B, Raina J, Lorenzo A, Busciglio J, Gabuzda D (1998) Neuronal apoptosis induced by HIV-1 tat protein and TNF- $\alpha$ : potentiation of neurotoxicity mediated by oxidative stress and implication for HIV-1 dementia. J Neurovirol 4:281-290

Song X, Bandow J, Sherman J, Baker JD, Brown PW, McDowell MT, Molloy MP (2008) iTRAQ experimental design for plasma biomarker discovery. J Proteome Res 7(7):2952-2958

Spellman DS, Deinhardt K, Darie CC, Chao MV, Neubert TA (2008) Stable isotopic labeling by amino acids in cultured primary neurons: application to brain-derived neurotrophic factordependent phosphotyrosine-associated signaling. Mol Cell Proteomics 7:1067-1076 
Speer R, Wulfkuhle JD, Liotta LA, Petricoin EF 3rd (2005) Reversephase protein microarrays for tissue-based analysis. Curr Opin Mol Ther 7:240-245

Storey JD, Tibshirani R (2003) Statistical significance for genomewide studies. Proc Natl Acad Sci USA 100:9440-9445

Sun B, Rempel HC, Pulliam L (2004) Loss of macrophage-secreted lysozyme in HIV-1-associated dementia detected by SELDI-TOF mass spectrometry. AIDS 18:1009-1012

Talley AK, Dewhurst S, Perry SW, Dollard SC, Gummuluru S, Fine SM, New D, Epstein LG, Gendelman HE, Gelbard HA (1995) Tumor necrosis factor alpha-induced apoptosis in human neuronal cells: protection by the antioxidant $\mathrm{N}$-acetylcysteine and the genes bcl-2 and crmA. Mol Cell Biol 15:2359-2366

Toro-Nieves DM, Rodriguez Y, Plaud M, Ciborowski P, Duan F, Pérez Laspiur J, Wojna V, Meléndez LM (2009) Proteomic analyses of monocyte-derived macrophages infected with human immunodeficiency virus type 1 primary isolates from Hispanic women with and without cognitive impairment. J Neurovirol 15:36-50

Torres G, Garcia V, Sanchez E, Segarra A, Patterson BK, MelendezGuerrero LM (2001) Expression of the HIV-1 co-receptors CCR5 and CXCR4 on placental macrophages and the effect of IL-10 on their expression. Placenta 22(Suppl A):S29-S33

Tuttle DL, Anders CB, Aquino-De Jesus MJ, Poole PP, Lamers SL, Briggs DR, Pomeroy SM, Alexander L, Peden KW, Andiman WA, Sleasman JW, Goodenow MM (2002) Increased replication of non-syncytium-inducing HIV type 1 isolates in monocyte-derived macrophages is linked to advanced disease in infected children. AIDS Res Hum Retroviruses 20(18):353362

Tsang J, Chain BM, Miller RF, Webb BL, Barclay W, Towers GJ, Katz DR, Noursadeghi M (2009) HIV-1 infection of macrophages is dependent on evasion of innate immune cellular activation. AIDS 23:2255-2263

Ulintz PJ, Yocum AK, Bodenmiller B, Aebersold R, Andrews PC, Nesvizhskii AI (2009) Comparison of MS(2)-only, MSA, and MS(2)/MS(3) methodologies for phosphopeptide identification. J Proteome Res 8:887-899

Van den Bergh R, Florence E, Vlieghe E, Boonefaes T, Grooten J, Houthuys E, Tran HT, Gali Y, De Baetselier P, Vanham G, Raes G (2010) Transcriptome analysis of monocyte-HIV interactions. Retrovirology 7:53

Velazquez I, Plaud M, Wojna V, Skolasky R, Laspiur JP, Melendez LM (2009) Antioxidant enzyme dysfunction in monocytes and CSF of Hispanic women with HIV-associated cognitive impairment. J Neuroimmunol 206:106-111

Wahl SM, Greenwell-Wild T, Vazquez N (2006) HIV accomplices and adversaries in macrophage infection. J Leukoc Biol 80:973-983

Wang T, Gong N, Liu J, Kadiu I, Kraft-Terry SD, Schlautman JD, Ciborowski P, Volsky DJ, Gendelman HE (2008) HIV-1-infected astrocytes and the microglial proteome. J Neuroimmune Pharmacol 3(3):173-186
Wiederin J, Rozek W, Duan F, Ciborowski P (2009) Biomarkers of HIV-1 associated dementia: proteomic investigation of sera. Proteome Sci 7:8

Williams AE, Blakemore WF (1990) Monocyte-mediated entry of pathogens into the central nervous system. Neuropathol Appl Neurobiol 16:377-392

Williams KC, Corey S, Westmoreland SV, Pauley D, Knight H et al (2001) Perivascular macrophages are the primary cell type productively infected by simian immunodeficiency virus in the brains of macaques: implications for the neuropathogenesis of AIDS. J Exp Med 193:905-915

Williams KC, Hickey WF (2002) Central nervous system damage, monocytes and macrophages, and neurological disorders in AIDS. Annu Rev Neurosci 25:537-562

Wojna V, Carlson KA, Luo X, Mayo R, Melendez LM, Kraiselburd E, Gendelman HE (2004) Proteomic fingerprinting of human immunodeficiency virus type 1-associated dementia from patient monocyte-derived macrophages: a case study. J Neurovirol 10 (Suppl 1):74-81

Wong JK, Gunthard HF, Havlir DV, Zhang ZQ, Haase AT, Ignacio CC, Kwok S, Emini E, Richman DD (1997) Reduction of HIV-1 in blood and lymph nodes following potent antiretroviral therapy and the virologic correlates of treatment failure. Proc Natl Acad Sci USA 94:12574-12579

Wu WW, Wang G, Baek SJ, Shen RF (2006) Comparative study of three proteomic quantitative methods, DIGE, cICAT, and iTRAQ, using 2D gel- or LC-MALDI TOF/TOF. J Proteome Res 5:651-658.

Xue Y, Yun D, Esmon A, Zou P, Zou S, Yu Y, He F, Yang P, Chen X (2008) Proteomic dissection of agonist-specific TLR-mediated inflammatory responses on macrophages at subcellular resolution. J Proteome Res 7(8):3180-3193

Yeh MW, Kaul M, Zheng J, Nottet HS, Thylin M, Gendelman HE, Lipton SA (2000) Cytokine-stimulated, but not HIV-infected, human monocyte-derived macrophages produce neurotoxic levels of L-cysteine. J Immunol 164:4265-4270

Yuan X, Desiderio DM (2005) Human cerebrospinal fluid peptidomics. J Mass Spectrom 40(2):176-181

Zhang L, Yu W, He T, Yu J, Caffrey RE, Dalmasso EA, Fu S, Pham T, Mei J, Ho JJ, Zhang W, Lopez P, Ho DD (2002) Contribution of human alpha-defensin 1, 2, and 3 to the anti-HIV-1 activity of CD8 antiviral factor. Science 298:995-1000

Zhu T (2002) HIV-1 in peripheral blood monocytes: an underrated viral source. J Antimicrob Chemother 50:309-311

Zhu T, Mo H, Wang N, Nam DS, Cao Y et al (1993) Genotypic and phenotypic characterization of HIV-1 patients with primary infection. Science 261:1179-1181

Zhu T, Muthui D, Holte S, Nickle D, Feng F, Brodie S, Hwangbo Y, Mullins JI, Corey L (2002) Evidence for human immunodeficiency virus type 1 replication in vivo in CD14+ monocytes and its potential role as a source of virus in patients on highly active antiretroviral therapy. J Virol 76(2):707-716 